\title{
StanfordLawSchool
}

\section{How Often Do Non-Practicing Entities Win Patent Suits?}

John R. Allison
McCombs Graduate School of Business, University of Texas
Mark A. Lemley
Stanford Law School
David L. Schwartz
Northwestern University School of Law

John M. Olin Program in Law and Economics Stanford Law School Stanford, California 94305

Working Paper Series

Paper No. 485

This paper can be downloaded without charge from the Social Science Research Network Electronic Paper Collection http://ssrn.com/abstract=2750128 


\title{
How Often Do Non-Practicing Entities Win Patent Suits? ${ }^{1}$
}

\author{
John R. Allison, ${ }^{2}$ Mark A. Lemley, ${ }^{3} \&$ David L. Schwartz ${ }^{4}$
}

Non-practicing entities (NPEs), some of which are also labeled patent assertion entities or "patent trolls," play a disputed role in our modern patent system. These entities, which do not make and sell products or services based on their patented technologies, file a large percentage of all patent lawsuits, and the perceived patent "troll" problem has dominated the discussion of patent reform in recent years. The policy debate is complicated by disagreement over who counts as a "patent troll," and by debates over whether NPEs are problematic in themselves or whether the real problem consists of entities (practicing or not) that assert weak patents.

In this article, we present empirical results that provide insight into both questions. Drawing on a comprehensive data set we built of every patent lawsuit filed in 2008 and 2009 that resulted in a ruling on the merits, we find that the situation is rather more complicated than simply operating companies vs. NPEs. While operating companies fare better in litigation

1 (C) 2016 John R. Allison, Mark A. Lemley, \& David L. Schwartz.

2 Spence Centennial Professor, McCombs Graduate School of Business, University of Texas at Austin.

3 William H. Neukom Professor, Stanford Law School; partner, Durie Tangri LLP, San Francisco, California.

4 Professor of Law, Northwestern University School of Law.

We thank Christopher Cotropia, Peter Detkin, Michael Frakes, Rose Hagan, Daniel Ho, Daniel Klerman, Scott Kominers, Lisa Ouellette, Lee Petherbridge, Michael Risch, and Ted Sichelman, and the participants at the University of San Diego School of Law $6^{\text {th }}$ Annual Patent Law Conference for their comments and suggestions. We also thank Kyle Rozema, Yang Zhai, and Yingda Shi for statistical assistance. 
than NPEs overall, breaking NPEs into different categories reveals more complexity. And once we remove certain pharmaceutical cases from the mix, no patent plaintiff fares very well. That is particularly true of software, computer, and electronics patents.

In Part I, we provide background on the debate over NPEs, including disagreement about the term "patent troll" itself. In Part II, we explain our methodology. We present our results in Part III, and discuss some implications and caveats in Part IV.

\section{The Trouble With "Trolls"}

NPEs, a subset of which are often referred to as patent trolls or "patent assertion entities" (PAEs), are the subject of much debate in the patent world. ${ }^{5}$ Complaints that trolls are perverting the patent system or interfering with innovation are common. For instance, NPR and John Oliver's "Last Week Tonight" have both run feature stories on the problems with "trolls." There is anecdotal evidence that some PAEs assert low quality patents and seek nuisance-value settlements, and Congress is currently considering new legislation directed at the "patent troll" problem. ${ }^{6}$

Although solid empirical work on NPEs is scarce, we do know that NPE suits are a significant feature of the patent system. They account for a majority of all defendants sued for patent infringement. ${ }^{7}$ The percentage of all patent lawsuits and accused infringers attributable to NPE-

5 Portions of this paragraph and the following one are adapted from Mark A. Lemley \& A. Douglas Melamed, Missing the Forest for the Trolls, 113 Colum. L. Rev. 2117 (2013).

6. PATENT Act, H.R. 9 (2015).

7 We use the term "assertions" to refer to the number of accused infringers (defendants in cases brought by patent owners.) 
instituted litigation is even higher in the information technology (IT) industry. ${ }^{8}$ Some studies

find that they win both larger judgments and larger settlements than do operating companies. ${ }^{9}$

However, other studies using the same data find the opposite. ${ }^{10}$ There are complaints that

NPEs often assert weak patents, 11 although empirical evaluation of patent quality metrics

sometimes used by economists suggest that NPE patents are stronger than operating company

8. Because NPEs tended to sue large numbers of defendants in single suits, at least until that became much more difficult with the passage of the AIA in 2011, it is important to focus on the number of assertions (that is, the number of defendants sued), not solely on the number of suits. A recent study coauthored by one of the authors of this paper found that operating companies were responsible for a minority of patent assertions in 2012. Christopher A. Cotropia, Jay P. Kesan, \& David L. Schwartz, Unpacking Patent Assertion Entities (PAEs), 99 Minn. L. Rev. 649 (2014) accord Colleen V. Chien, Patent Trolls by the Numbers (Santa Clara Univ. Legal Studies Research Paper No. 08-13, 2013), available at http://papers.ssrn.com/abstract=2233041. But see Robin Feldman, Tom Ewing \& Sara Jeruss, The AIA 500 Expanded: The Effects of Patent Monetization Entities, 17 UCLA J.L. \& Tech. 1 (2013) (finding that "patent monetization entities, yet another term for PAEs, filed $58.7 \%$ of the patent lawsuits); Colleen V. Chien, Of Trolls, Davids, Goliaths, and Kings: Narratives and Evidence in the Litigation of High-Tech Patents, 87 N.C. L. Rev. 1571 (2009).

9. The 2012 PricewaterhouseCoopers study of patent litigation found that NPEs won damages awards almost twice as high on average as those won by practicing entities. PwC, 2012 Patent Litigation Study 5 (2012), available at http://www.pwc.com/en US/us/forensic-services/publications/assets/2012patent-litigation-study.pdf (on file with the Columbia Law Review).

10. Michael J. Mazzeo, Jonathan H. Ashtor \& Samantha Zyontz, Do NPEs Matter? Non-Practicing Entities and Patent Litigation Outcomes, 9 J. Competition L. \& Econ. 879 (2013) ("[W]e find no significant differences in the distribution of awards between NPEs and practicing entities."). The difference appears to be that Mazzeo et al. control for the nature of the defendants being sued, and NPEs target somewhat different defendants than operating companies.

11. See Robert P. Merges, The Trouble with Trolls: Innovation, Rent-Seeking, and Patent Law Reform, 24 Berkeley Tech. L.J. 1583, 1603-04 (2009) (discussing allegations that trolls file suits on weaker patents). But see Shawn P. Miller, Patent "Trolls": Rent-Seeking Parasites or Innovation-Facilitating Middlemen?, http://papers.ssrn.com/abstract=1885538 (finding "trolls" generally litigate higher quality patents than practicing entities based upon patent citation counts). 
patents. ${ }^{12}$ There is evidence that the most-litigated NPE-owned patents are more likely than other patents to lose in court. ${ }^{13}$

The evidence on the social costs and benefits of NPEs is highly contested. One study calculates that NPEs cost private firms ${ }^{14}$ approximately $\$ 30$ billion per year ${ }^{15}$ and another study by the same primary authors estimated a total NPE cost of $\$ 500$ billion over the past twenty

12. See Michael Risch, Patent Troll Myths, 42 Seton Hall L. Rev. 457, 478-81 (2012) (finding higher forward citations in the most litigious NPEs' patents); accord John R. Allison \& Mark A. Lemley, Extreme Value or Trolls on Top: The Characteristics of the Most-Litigated Patents, 158 U. Penn. L. Rev. 1, 13-16 (2009) (finding higher forward citations and self-citations in the most litigated patents). Notably, however, the use of those metrics to assess patent quality has itself been questioned, by some of the authors and others. See, e.g., John R. Allison et al., Understanding the Realities of Modern Patent Litigation, 92 Tex. L. Rev. 1769 (2014).

13. See John R. Allison, Mark A. Lemley, and Joshua Walker, et al., Patent Quality and Settlement Among Repeat Patent Litigants, 99 Geo. L.J. 677, 694 (2011) [hereinafter Allison et al., Patent Quality] (finding troll suits were much less likely than operating company suits to result in a patentee win); Shawn P. Miller, Where's the Innovation: An Analysis of the Quantity and Qualities of Anticipated and Obvious Patents, 18 Va. J.L. \& Tech. 1, 29-31, 49-50 (2013) (finding that troll patents are more likely to be invalidated on prior art grounds); Mazzeo et. al., supra note __ at 890 (finding individual inventors had a lower success rate than "NPE - companies," which had a lower success rate than non-NPEs from 1995-2011). But see Michael Risch, A Generation of Patent Litigation, 52 San Diego L. Rev. 67, 120 table 16 (2015) (finding that the more often a patent is asserted, the more likely it is to be invalidated, but that, in the aggregate, patents asserted many times are less likely to be held invalid.) Shawn P. Miller, What's the Connection Between Repeat Litigation and Patent Quality? A (Partial) Defense of the Most Litigated Patents, 16 Stan. Tech. L. Rev. 313, 334, 336 (2013) [hereinafter Miller, Most Litigated Patents], (using different measurement than Allison et al. and finding troll-owned most-litigated patents are more successful than other patents). Notably, the Allison et al. study focused on the most-litigated patents, and those patents (which are disproportionately owned by NPEs) likely have different characteristics than other patents.

14. Some of these studies purport to measure the "social" costs, but empirically only measure the costs to private firms. For a discussion of the distinction between social and private firm costs, see Lisa $\mathrm{L}$. Ouellette, Patent Costs and Benefits, http://writtendescription.blogspot.com/2013/07/costsbenefits.html.

15. James Bessen \& Michael J. Meurer, The Direct Costs from NPE Disputes, 99 Cornell L. Rev. 387 (2014). 
years. ${ }^{16}$ Both of these studies have been repeatedly criticized, however, including by one of the authors, both on flawed techniques and biased data sources. ${ }^{17}$

There are those who defend NPEs on policy grounds. One common defense tends to be that PAEs - NPEs who purchase patents from others - can serve as business intermediaries between inventors and commercializers. ${ }^{18}$ That claim, too, is controversial, both as a matter of

16. James Bessen et al., The Private and Social Costs of Patent Trolls 17 (Bos. Univ. Sch. of Law Working Paper No. 11-45, 2011), available at http://ssrn.com/abstract=1930272.

17 For criticism of $\$ 30$ billion study and its methodology, see David L. Schwartz \& Jay P. Kesan, Analyzing the Role of Non-Practicing Entities in the Patent System, 99 Cornell L. Rev. 425 (2014). Schwartz \& Kesan also criticized as "facially implausible" the other study, which used stock market movements to argue that each NPE lawsuit caused each defendant to drop in market capitalization between $\$ 122$ million and $\$ 140.6$ million at the mean. Id. at 447-48. See also Ron D. Katznelson, Questionable Science Will Misguide Patent Policy - the $\$ 83$ Billion per Year Fallacy (available at http://papers.ssrn.com/sol3/papers.cfm?abstract id=2502777 (arguing that there are "fundamental flaws" in methodology used by Bessen \& Meurer); see also Joff Wild, There Are Now Very Serious Questions to be Asked of that Bessen \& Meurer \$29 Billion NPE Costs Claim, IAM Blog (June 7, 2015) (available at http://www.iam-media.com/blog/detail.aspx?g=7c964cea-31fa-469a-99eb-8c5e2ee11818) (questioning why Bessen \& Meurer's calculations are over 300\% higher than calculations by RPX, the source of Bessen \& Meurer's proprietary data).

18 Daniel Spulber, new paper; James F. McDonough III, The Myth of the Patent Troll: An Alternative View of the Function of Patent Dealers in an Idea Economy, 56 Emory L.J. 189 (2006); Ashish Arora \& Robert P. Merges, Specialized Supply Firms, Property Rights, and Firm Boundaries, 13 Indus. \& Corp. Change 451 (2004); Robert P. Merges, A Transactional View of Property Rights, 20 Berkeley Tech. L.J. 1477 (2005). For discussion of this patent market idea, see, e.g., Stephanie Chuffart-Finsterwald, Patent Markets: An Opportunity for Technology Diffusion and FRAND Licensing?, 18 Marq. Intell. Prop. L. Rev. 336 (2014); Michael Risch, Licensing Acquired Patents, 21 Geo. Mason L. Rev. 979 (2014); Ryan Holte, Trolls or Great Inventors: Case Studies of Patent Assertion Entities, 59 St. L. U. L.J. 1 (2014); Damien Geradin, Anne Layne-Farrar \& A. Jorge Padilla, Elves or Trolls? The Role of Nonpracticing Patent Owners in the Innovation Economy, 21 Indust. \& Corp. Change 73, 87 (2011); Andrei Hagiu \& David B. Yoffie, The New Patent Intermediaries: Platforms, Defensive Aggregators, and Super-Aggregators, $27 \mathrm{~J}$. of Econ. Perspectives 45 (2013).

On the commercialization theory of patents, see Michael Abramowicz, The Danger of Underdeveloped Patent Prospects, 92 Cornell L. Rev. 1065 (2007); accord F. Scott Kieff, Property Rights and Property Rules for Commercializing Inventions, 85 Minn. L. Rev. 697 (2001); Michael Abramowicz \& John F. Duffy, Intellectual Property for Market Experimentation, 83 N.Y.U. L. Rev. 337 (2008); Ted Sichelman, Commercializing Patents, 62 Stan. L. Rev. 341, 345 (2010). 
theory and of evidence. ${ }^{19}$ There is some limited evidence that ex post patent demands do not generate much if any technology transfer or other direct innovation, whether delivered by NPEs or operating companies. ${ }^{20}$ Some argue that ex post patent trade and licensing may nonetheless be socially valuable. ${ }^{21}$ And some argue that ex ante licensing (after patenting but before commercialization) will not operate efficiently without a credible threat of ex post or ex ante litigation. $^{22}$

Part of the difficulty comes from a lack of clarity in defining who exactly we are talking about. The pejorative term "troll" is used by some to refer to any party that doesn't actually produce goods or services. Indeed, some use troll to refer to anyone who is suing them, even practicing entities. ${ }^{23}$ Others would exclude some entities - notably universities and individual inventors - from the troll definition. Still others would limit patent trolls further, to include only PAEs - companies whose primary line of business is filing patent suits. And even that definition is too broad for some, who would limit the term patent troll to those who assert

19 For critiques of commercialization theory, see, e.g., Mark A. Lemley, The Myth of the Sole Inventor, 110 Mich. L. Rev. 709 (2012); Mark A. Lemley, Ex Ante Versus Ex Post Justifications for Intellectual Property, 71 U. Chi. L. Rev. 129 (2004).

20 Robin C. Feldman \& Mark A. Lemley, Do Patent Licensing Demands Mean Innovation?, 101 lowa L. Rev. 137 (2015) (finding in a survey of licensing managers that ex post patent licensing demands almost never lead to technology transfer from NPEs to targets).

21 Alberto Galasso, Mark Schankerman \& Carolos J. Serrano, Trading and Enforcing Patent Rights. 44 RAND J. of Econ., 275 (2013).

${ }^{22}$ Michael Risch, Licensing Acquired Patents, 21 Geo. Mason L. Rev. 979 (2014).

23 Thus, in the Ditto.com example discussed above, the "troll" was actually a larger competitor, 1-800Contacts. Most people would agree that operating companies that compete in the field in which they sue are not trolls. Ted Sichelman calls them "patent bullies," at least when the underlying patents are weak. Ted Sichelman, The Vonage Trilogy: A Case Study in Patent Bullying, 90 Notre Dame L. Rev. 543 (2014). Colleen Chien calls them "goliaths." Chien, supra note _, at _. For a discussion of the lack of consistency and transparency in the use of the term 'patent troll,' see Michael Risch, Framing the Patent Troll Debate, 24 Expert Opinion on Therapeutic Patents 127 (2014). 
patents they bought from others, only those who assert invalid patents, or only those who engage in certain "abusive" tactics in patent litigation such as pressuring allegedly infringing manufacturers by threatening those manufacturers' end-user customers, or seeking nuisancevalue settlements. The definitional question is sufficiently muddled that two of the authors designed a taxonomy of twelve different entity types, allowing people to decide for themselves who fits in the troll category. ${ }^{24}$ The third author separately designed a taxonomy of eight different entity types, and further released raw data from lawsuits filed in 2010 and 2012 to permit other researchers to study filing trends. ${ }^{25}$

Further complicating matters, NPEs can differ in their business models regardless of whether they are asserting good patents or bad ones, their own patents or acquired ones. Mark Lemley and Doug Melamed have distinguished three troll business models: (1) "bottomfeeder" trolls interested only in a nuisance-value settlement, ${ }^{26}$ (2) "lottery ticket" trolls interested in taking a case to trial for a big payoff, ${ }^{27}$ and (3) "aggregators" who bundle numerous patents to license as a package. ${ }^{28}$ David Schwartz has argued that another model likely exists, falling between Lemley \& Melamed's "bottom feeder" PAEs and "lottery ticket"

24 John R. Allison, Mark A. Lemley, \& Joshua Walker, Extreme Value or Trolls on Top? The Characteristics of the Most-Litigated Patents, 158 U. Pa. L. Rev. 1 (2009).

25 Christopher A. Cotropia, Jay P. Kesan \& David L. Schwartz, Unpacking Patent Assertion Entities, 99 Minn. L. Rev. 649 (2014).

26 In an article on contingent fee representation in patent cases, David Schwartz describes a similar phenomenon in contingent fee lawyers in patent cases, referring to lawyers at the "bottom" of the market as those seeking nuisance-value settlements. David L. Schwartz, The Rise of Contingent Fee Representation in Patent Litigation, 64 Ala. L. Rev. 335, 344, 369-71 (2012).

${ }^{27}$ David Schwartz referred to contingent fee lawyers seeking huge payments for a small number of alleged infringers as being at the "top" of the market. Id. at 362-64.

28

Lemley \& Melamed, supra note _ , at _. 
PAEs, and that PAEs in this additional category assert patents with some legal merit. ${ }^{29}$ Moreover, the category that we and others refer to as "operating companies" is likewise not monolithic. Operating companies sometimes spin off patents to separate entities in an effort to monetize their patent assets (or to harass their competitors), a practice called patent "privateering." ${ }^{30}$ And because PAEs predominate in some technologies and industries but are virtually absent in others, the success of PAEs suits is bound up with the differential success rates of patents in those different sectors. ${ }^{31}$

Finally, the asserted problems with patent trolls are a reflection of more general problems with patent litigation, perhaps most notably the phenomenal cost of such litigation. ${ }^{32}$ As Lemley and Melamed argue,

Understanding the economics of patent assertions by both trolls and practicing entities allows us to move beyond labels and the search for "bad actors" and to focus instead on aspects of the patent system itself that give rise to the problems and on specific, objectionable conduct in which both trolls and practicing entities sometimes engage. Patent trolls alone are not the problem; they are a symptom of larger problems with the patent system. Treating the

29 David L. Schwartz, On Mass Patent Aggregators, 114 Colum. L. Rev. Sidebar 51, 54 (2014).

30 See id. at _; John M. Golden, Patent Privateers: Private Enforcement's Historical Survivors, 26 Harv. J. L. \& Tech. 545 (2013); Tom Ewing \& Robin Feldman, The Giants Among Us, 2012 Stanford Tech. L. Rev. 1 (2012).

31 We study technology- and industry-specific differences in patent litigation win rates in our companion paper. See John R. Allison, Mark A. Lemley, \& David L. Schwartz, Our Divided Patent System, 82 U. Chi. L. Rev. 1073 (2015).

32 In 2013, the average cost per party in relatively small patent infringement cases with stakes of between $\$ 10$ and $\$ 25$ million was $\$ 2.2$ million through pretrial discovery and $\$ 3.6$ million through trial. Amer. Intell. Prop. Ass'n, Report of the Economic Survey 31 (2013). The average cost of defending against a patent infringement case brought by an NPE (as defined by AIPLA) was a bit lower: \$1.7 million through discovery and $\$ 2.7$ million through trial. The latter fact is probably attributable in major part to the absence of patent infringement counterclaims in a case brought by an NPE because an NPE does not make or sell products or services that can form the basis of an infringement counterclaim by the defendant. 
symptom will not solve the problems. In a very real sense, critics have been missing the forest for the trolls. ${ }^{33}$

The result is that the political and legal debate over PAEs has become bound up in definitional disputes and tied to larger debates over the value of the patent system as a whole and its differential effects in different industries. ${ }^{34}$ Our hope in this paper is to return some empirical grounding to those debates by providing evidence on an important issue (though by no means the only important one): how different types of patent plaintiffs actually fare in the small subset of cases which reach a merits ruling. While others have studied how the most litigious PAEs ${ }^{35}$ or the most litigated patents ${ }^{36}$ have fared, no one has previously analyzed the outcomes of all of the patents asserted in litigation. In this Article, we analyze merits rulings of all patent lawsuits filed during a 2-year window, moving substantially beyond the work of previous researchers.

\section{Methodology}

In this Part, we explain in detail the techniques that we used to locate and collect the data. ${ }^{37}$ We describe the data sources and provide information about the coders, our process of

33 Lemley \& Melamed, supra note __, at _.

34 On the different way patents affect different industries, see Dan L. Burk \& Mark A. Lemley, The Patent Crisis and How the Courts Can Solve It (2009).

35 Michael Risch, The Layered Patent System, 101 lowa L. Rev. (forthcoming 2015); Michael Risch, Patent Troll Myths, 42 Seton Hall L. Rev. 457 (2012).

${ }^{36}$ John R. Allison, Mark A. Lemley \& Joshua Walker, Extreme Value or Trolls on Top? The Characteristics of the Most-Litigated Patents, 158 U. Pa. L. Rev. 1 (2009).

37 We plan to release the data set to the public after the publication of this article. 
selecting data for inclusion in the data set, and the way we have categorized cases into technology, industry, and entity status categories. We also discuss some of the limitations of our approach. ${ }^{38}$

\section{A. Data Collection}

Electronic-filing requirements mean that the online-filing tool of the federal courts, Public Access to Court Electronic Records (PACER), has a nearly complete collection of litigation documents from patent cases since $1999 .^{39}$ Some scholars have taken advantage of PACER data to analyze district court decisions in the early 2000s, when NPE litigation was not substantial. ${ }^{40}$ Although the raw data provided by the Administrative Office of the United States Courts has coded case outcomes for more recent years, the data is notoriously error-prone, ${ }^{41}$ and it does a poor job of classifying outcomes. ${ }^{42}$

38 Portions of this Section are adapted from our prior papers to the extent that this paper reflects the same methodology. See generally John R. Allison, Mark A. Lemley, \& David L. Schwartz, Understanding the Realities of Modern Patent Litigation, 92 Tex. L. Rev. 1769 (2014).

39 For a discussion of PACER coding and its shortcomings, see generally Matthew Sag, Empirical Studies of Copyright Litigation: Nature of Suit Coding (Loyola University Chicago School of Law Public Law \& Legal Theory Research Paper No 2013-017, Sept 2013), archived at http://perma.cc/N8HX-U4G2. For information on PACER's completeness since 1999, see Alan P. Marco, Shawn C. Miller \& Ted Sichelman, Do Economic Downturns Dampen Patent Litigation?, 12 J. Empirical L. Stud. 481, 488 n.39 (2015).

40 See, for example, Jay P. Kesan \& Gwendolyn G. Ball, How Are Patent Cases Resolved? An Empirical Examination of the Adjudication and Settlement of Patent Disputes, 84 Wash. U. L. Rev. 237, 261 (2006) (examining the online docket reports available through the PACER system).

41 See id (finding that a substantial percentage of cases were misclassified as patent cases). See also Kimberly A. Moore, Judges, Juries, and Patent Cases—an Empirical Peek inside the Black Box, 99 Mich. L. Rev. 365, 381 (2000) (eliminating some cases misclassified as patent trials from the data set).

42 See Kesan and Ball, supra note _ at 265 (explaining that the Administrative Office of the United States Courts' categories for case disposition are "rather ambiguous"). 
Consequently, we used the Lex Machina database as our data source. ${ }^{43}$ Lex Machina provides convenient access to cleaned and verified PACER data for district court patent litigation, which permitted us to carefully study all patent lawsuits. The Lex Machina data set offers three primary benefits. First, it includes all lawsuits-even those without a decision available on Westlaw or Lexis-and thus captures some district court decisions that the latter two sources may miss. ${ }^{44}$ Second, Lex Machina has cleaned and evaluated the PACER data, eliminating many of the errors in the raw data. ${ }^{45}$ Finally, Lex Machina has indexed the cases to identify summary judgment rulings, trial events, and appeals. ${ }^{46}$

Our study covers all patent lawsuits filed in federal district courts between January 1, 2008, and December 31, 2009. We selected the years 2008 and 2009 for several reasons. First, those years are sufficiently recent to provide a snapshot of current patent litigation. ${ }^{47}$ Second, because the cases were initiated several years ago, the overwhelming majority of those cases were finally resolved or settled before our project began. ${ }^{48}$ Lex Machina graciously provided us

43 See www.lexmachina.com.

44 See Features (Lex Machina, 2015), archived at https://perma.cc/UNJ6-SE9W ("[V]iew all patent case outcomes for a specific judge or district, displayed in easy-to-read charts and graphs supported by interactive case lists.").

45 See How It Works (Lex Machina, 2015), archived at https://perma.cc/75XN-GP4E (“Lex Machina cleans, codes, and tags all data.").

46 See id ("We identify all asserted patents, findings, and outcomes, including any damages awarded. We also build a detailed timeline linking all the briefs, motions, orders, opinions, and other filings for every case.").

${ }^{47}$ We discuss various doctrinal and procedural changes since 2009 in Section I.D, infra.

48 We conducted the outcome coding in the late summer and fall of 2013. As of February 2014, it appeared that only 2 to 3 percent of cases from the years 2008 and 2009 were still open. See Dennis Crouch, Pendency of Patent Infringement Litigation (Patently-O, Feb 17, 2014), archived at http://perma.cc/AV4J-J3LW. See also Kesan and Ball, supra note _, at 246 (defending the decision to study cases by year filed rather than by year terminated). 
with a list of lawsuits from the years 2008 and 2009 that contained at least one ruling on summary judgment or trial. Lex Machina furnished a second list of lawsuits from the same years, including cases with an appeal but without a summary judgment ruling or trial. The second list allowed us to capture cases in which the parties stipulated to judgment based upon a claim-construction decision with the goal of placing the case in condition for appeal. Both lists provided by Lex Machina included basic information about each lawsuit, including the judicial district in which the case was filed, the identity of the district court judge, and the filing date of the lawsuit.

From the cases provided by Lex Machina, we excluded lawsuits that did not include a complaint either alleging infringement of a utility patent or seeking declaratory relief of noninfringement or invalidity of a utility patent. Thus, we excluded inventorship and licensing disputes, malpractice actions, false marking suits, and allegations of design or plant patent infringement. After removing these lawsuits, we reviewed the docket report in detail, reading all relevant orders, opinions, motions, verdicts, appellate rulings, and other necessary court documents to code the litigation outcomes.

Because many of the dockets were extremely complicated-it was not uncommon for a patent case to have over 500 docket entries-we felt that student coders would be ill-suited to the task. Coding of outcomes, especially in patent cases, is notoriously difficult and time consuming, requiring deep knowledge of patent law and litigation as well as the motivation to devote long hours to the task. Consequently, two of the authors (Lemley and Schwartz) each personally coded the litigation-outcome information for approximately half of the lawsuits. Both Lemley and Schwartz are experienced patent litigators as well as academics who 
understand how to read a docket and appreciate complex litigation rulings. The hand coding

was extremely time intensive; it took several hundred hours in the aggregate. To permit an evaluation of the reliability and consistency of the coding, Lemley and Schwartz also overlapped in their coding of approximately 10 percent of the lawsuits. ${ }^{49}$

We use a patent-case combination as the unit of analysis. For each case, we coded the outcome separately for each asserted patent. For instance, if the jury returned a verdict on two patents, we recorded separately what occurred for each patent. ${ }^{50}$ For each patent, we also

49 Lemley and Schwartz each initially coded approximately 5 percent of the cases. Thereafter, they compared results and fine-tuned the codebook. For coding of the remaining cases, Lemley and Schwartz overlapped in 10 percent of the initial list of cases provided by Lex Machina. Some of the cases provided by Lex Machina turned out not to have relevant merits decisions. After a manual review of the dockets, the 10 percent overlap resulted in 30 patent cases with duplicate coding. To increase the amount of overlap and permit the use of statistical tests to report intercoder reliability, Schwartz additionally coded another random 15 percent overlap with Lemley, for an additional 46 patent cases with duplicate coding. We chose Cohen's kappa (ㅌ) as the measure of intercoder reliability. See Mark A. Hall and Ronald F. Wright, Systematic Content Analysis of Judicial Opinions, 96 Cal. L. Rev. 63, 113-14 (2008) (stating that the best practice for evaluating coding reliability is to report an agreement coefficient, such as $\underline{k})$. $\underline{\mathrm{k}}$ ranges from 0 to 1 , with numbers near 1 indicating a higher degree of reliability. See id (explaining that a 0 indicates "agreement entirely by chance" and that a 1 indicates "perfect agreement"). For the basic definitive and interim winners in cases, $\underline{\mathrm{k}}$ was 0.9534 , equating to near perfect agreement. For grants of motions for summary judgment on invalidity and noninfringement, $\underline{\mathrm{K}}$ was 0.9793, which also equates to near-perfect agreement for times in which we both identified motions. However, one of us found one additional motion for summary judgment of invalidity (forty versus thirty-nine). For motions for summary judgment on noninfringement, we each identified motions that the other did not (forty-two motions were found by both authors; one found forty-three motions, while the other identified forty-four motions). We revisited the overlapping case dockets again to understand these additional rulings, and we found that the additionally identified rulings should be included. We corrected all known disagreements in the data set. We believe that these differences in coding are due to the complexity of the dockets, and we do not believe that they are biased in one direction or another. We do believe, however, that the reliability information suggests that we slightly undercounted the number of merits rulings, although we cannot be sure whether the actual number should have more denials or grants.

50 Occasionally, the court ruled differently on different claims of a patent. For instance, a first claim may be infringed and not invalid, while a second claim was not infringed and invalid because it was "anticipated" by a prior patent or printed publication revealing the same invention. In these cases, we created a new record for each claim or group of claims that had a different substantive outcome, thus 
obtained a variety of patent demographic information and various facts about the lawsuit in question. We reported those findings in our companion papers, and we detail the information we collected there. ${ }^{51}$ We coded each civil action separately. ${ }^{52}$ If multiple civil actions involved the same patent, we coded them as separate observations, even if the lawsuits were consolidated. The descriptive statistics that we report below include each patent in each civil action, even those in consolidated lawsuits. However, our regression models take into account consolidated lawsuits, since we cluster standard errors at both the patent and case level.

For each patent in a lawsuit, the coders reviewed and captured all rulings on summary judgment relating to a patent-law issue. This includes rulings on motions of summary judgment on noninfringement, infringement, validity, invalidity, no inequitable conduct, and inequitable conduct. We excluded rulings on issues that were not patent specific, such as laches. We also excluded summary judgment rulings on patent-law issues if the court did not reach the merits of those issues-such as denials of summary judgment motions on the grounds that they were premature. The coders also reviewed and recorded all trial outcomes, whether there was a jury or bench trial, as well as decisions on post-verdict motions for judgment as a matter of law. Finally, we recorded whether an appeal was lodged, and how the appeal was resolved. The resolution data set includes whether the ruling on the patent was affirmed or reversed on appeal, or whether an appeal is pending or was dismissed (typically because the case settled).

taking the unit of observation down from the level of the patent to the level of the individual claim or group of claims.

51 See Allison, Lemley, and Schwartz, Understanding, supra note _, at 1179-80.

52 We treated a patent in a lawsuit as a single observation even if the patent was asserted against multiple parties in the same suit. 
When the underlying trial or appellate court opinion lacked sufficient detail to ascertain the basis for the ruling, we read the underlying briefing by the parties.

We coded merits decisions at a low level of granularity. For invalidity, we coded whether the ruling was based on utility, patentable subject matter, $\S 102$ prior art, $^{53}$ obviousness, indefiniteness, written description, enablement, or best mode. We also coded various bases for $\S 102$ invalidity. For infringement, we captured literal infringement, infringement under the doctrine of equivalents, and various types of indirect infringement. We also coded unenforceability, as well as the basis for the unenforceability argument. In addition to the separate coding of issues for summary judgment and trial, we also recorded the final resolution for each patent on the issues of infringement, validity, and enforceability.

We coded all the issues litigated to decision, whether or not that decision resulted in a trial outcome or a grant of summary judgment. Thus, if an accused infringer argued that the patent was invalid for lack of patentable subject matter, anticipation, and obviousness, and the court denied the first two arguments but granted the third, each of those three rulings shows up in our data set. ${ }^{54}$ To understand how the final-resolution variables were coded, one should understand that denial of summary judgment does not result in a final resolution. Instead, denial of summary judgment means that there is an unresolved disputed issue of material

53 See 35 USC $\S 102$.

54 To be clear, while we included merits rulings on each issue, we did not include the issue if the court denied the motion as moot. For instance, if the court granted summary judgment of anticipation on the merits and simultaneously denied summary judgment of obviousness as moot, we included anticipation but not obviousness. 
fact. ${ }^{55}$ Consequently, while we recorded all denials of summary judgment, they alone do not result in a final ruling in either direction. If, however, the issue had been resolved at trial, then the final ruling was coded as the trial resolution. If summary judgment had been granted on an issue, then the summary judgment ruling was coded as the final resolution in our coding. ${ }^{56}$ We coded decisions that finally ruled for a party on an issue as definitive wins, and decisions that ruled for a party but kept the issue alive (largely denials of summary judgment but also remands on appeal) as interim wins.

\section{B. Technology and Industry Classifications}

In our second companion paper, we focused on comparing outcomes across the technology and industry categories of the asserted patents. ${ }^{57}$ Our technology categories refer to the nature of the invention itself, while our industry categories focus on the owner of the patents and the industry in which the technology is put to use.

While the U.S. Patent and Trademark Office (PTO) has a technology classification scheme, it was not created for the purpose of defining technologies at a conceptual level, employs definitions at a very low level of functional abstraction, and possesses other serious

\section{See Fed. R. Civ. Proc. 56.}

56 If the Federal Circuit reversed a ruling relating to a patent on appeal, we updated the finalresolution coding to reflect the appellate decision. If the ruling was reversed on appeal, we retained the original decision in our summary judgment coding (though not our final-resolution coding) because we wanted to capture summary judgment win rates at the trial court. We don't believe that this coding decision meaningfully affects our results. Many grants of summary judgment weren't subject to an appeal and most appeals resulted in at least partial affirmance. Even some reversals were retried to the same result. Only a small percentage (less than 10 percent) of patents ruled invalid or not infringed on summary judgment were subject to a complete reversal followed by settlement in our data set.

John R. Allison et al., Divided, supra note _. 
shortcomings that have been discussed in connection with prior research published by two of this Article's authors. ${ }^{58}$ We wanted a series of broad categories that would capture inventions of different types. As a result, one of us (Allison) evaluated all of the patents in our study by hand and categorized them into one of six different technology areas and one of eleven different industry categories. We discuss the definitions of each of those categories in detail in our companion paper. ${ }^{59}$ We include in this paper breakdowns by both technology and industry category.

\section{Entity Status}

The heart of this paper is our discussion of patent litigation outcomes by entity status. As we noted above, there are many different business models among patent plaintiffs and considerable debate over what entities are properly classified as patent trolls. Two of the authors, Allison and Lemley (along with Walker) have previously categorized patent owners into twelve different types. ${ }^{60}$ The third has previously categorized patent owners into eight different types. ${ }^{61}$ The Stanford Entity Status Project is currently in the process of classifying all patent plaintiffs since 2000 into one of thirteen different categories, building on and expanding the Allison-Lemley-Walker taxonomy.

58 See John R. Allison, Mark A. Lemley, Kimberly A. Moore, \& Derek Trunkey, Valuable Patents, 92 Geo. L.J. 435, 438 n 15 (2004) (discussing these shortcomings). When a researcher works with an extremely large data set such that it is not feasible to study each patent in depth as was done here, reliance on PTO classifications or International Patent Classifications may be an unavoidable shortcut.

Allison et al., Divided, supra note _, at _.

Allison et al., Extreme Value, supra note _, at _.

Cotropia et al., Unpacking Patent Assertion Entities, supra note _ , at _. 
We hand-coded entity status results. Sometimes the coding was obvious, as was true in the case of suits by individuals, universities, and some of the larger operating companies. Where the coding was not evident, one of us (Schwartz) reviewed the complaints in the cases and the web site of the plaintiff firm to seek to identify the predominant nature of the plaintiff's business model. We cross-checked that coding against the coding currently being done by the Stanford Patent Entity Status Project, which includes all of our cases, to identify and further investigate any discrepancies in coding. There were disagreements in less than $10 \%$ of the parties. Some of the disagreements occurred because there was little available information about some patent plaintiffs, partially because of the time lag between the lawsuits and the present study. The lawsuits were brought six to seven years ago. The disagreements were resolved and corrected in the coding. Eventually, we coded every entity asserting a patent in our dataset.

In classifying the cases in our data set, however, we found that many of these categories had few if any cases in the years we studied. Further, classifying an entity as, for example, a start-up spun off from a university that had never made a product, or a pre-product start-up that had not yet made a product but still planned to do so, turned out to be quite difficult. And given that there were relatively few cases in each category, we opted for a smaller number of broader, more functional entity categories.

Accordingly, we collapsed some categories and divided patent plaintiffs into one of five exclusive groups (which are a subset of both the previous Allison-Lemley-Walker methodology, and the Cotropia-Kesan-Schwartz methodologies): operating company, university, individual, failed start-up/failed operating company, and patent holding company (including aggregators). 
With effort, we were able to classify all of our patent holders into one of these categories. We refer to patent holding companies as our narrow definition of PAE. We classified a patent holder as a university if a university was the sole plaintiff. If there was a co-plaintiff that was an operating company-such as a pharmaceutical company-we assumed that the operating company controlled the litigation and classified the lawsuit as one maintained by an operating company patent holder. Spinoffs from universities were not treated as university patent holders. They were treated as an operating company or failed company, depending upon whether they manufactured products at the time of the lawsuit.

We treated a patent holder as a failed startup or company if there was evidence that the company manufactured products or performed services or attempted to do the same at some point in the past, but no longer did. We attempted to measure this as of the time of filing the lawsuits - either 2008 or 2009 . We classified companies that were owned entirely by an individual inventor as an individual inventor. For instance, according to judicial opinions, Ergo Licensing LLC is a licensing company owned solely by one of the original inventors of the patent. ${ }^{62}$ Ergo appears to have been created to license the patent, not to attempt to commercialize it. In our coding, we differentiated companies like this that are comprised of only the inventor with lawsuits initiated by an individual inventor in his or her personal capacity. However, in both instances, the inventor, whether litigating as a personal owner of the patent or as an owner of a shell corporation that owns the patent, presumably received substantially all of the net proceeds of the litigation and likely directed the litigation strategy. For purposes

\footnotetext{
62 See http://www.med.uscourts.gov/Opinions/Rich/2009/JHR_07132009_208cv259_Ergo_v_Cardinal_AFFIRMED_08192009.pdf.
} 
of our analyses in this Article, we collapsed the categories of individual litigating in an individual capacity and individual litigating in corporate form into a single category called "Individual." We also ran a separate analysis for each of our results in which we compared operating companies with everyone else - the latter category we call simply "NPE."

Our choice of categories necessarily leaves out some information we might wish to know. We found no way, for instance, to reliably categorize operating companies based on whether the patent they were asserting was one they actually practiced, one that they employed to keep competitors out of a given space but did not use as the basis for making a product or service, or one that was in a field in which they did not operate at all (in which case it is effectively an NPE with respect to that patent). Similarly, the distinction between individualowned patents and failed start-up patents can sometimes (but not always) be difficult to ascertain, as it was hard to determine whether a company made efforts to commercialize or was formed merely to attempt to limit liability before initiating litigation. It was difficult for us to ascertain whether a company was a failed startup or just a company formed by the individual inventor. Nonetheless, we think these divisions capture significant differences in business models, and allow for a more nuanced analysis than would be achieved by merely distinguishing operating companies from NPEs.

Our analysis of the data is cumulative of that of the other two papers. In our first paper, we evaluated the characteristics of individual patents to see how they correlated with litigation outcomes. $^{63}$ In our second paper, we added industry and technology characteristics to the

63 Allison et al., Understanding, supra note _. 
existing set of patent variables to help explain variance in patent litigation outcomes. ${ }^{64}$ In this paper, we retain those explanatory variables and add our new variables for entity status. ${ }^{65}$

Thus, the logistic regressions we report in the next Part include not only entity status but also most of the other independent variables from the last two papers as explanatory factors. ${ }^{66}$

\section{Potential Limitations}

Our data set and the implications that can be drawn therefrom are subject to several limitations. For brevity, we discuss three important limitations here.

First, our data set is limited to lawsuits filed in the years 2008 and 2009 . Thus, it is only a snapshot of the larger flow of litigation. The 2008 and 2009 lawsuits may or may not be

64 Allison et al., Divided, supra note _.

65 We use logistic regression (or logit) models, because each of our dependent variables (specific outcomes) is binary ("yes" or "no"). Although multivariate regression assumes that all observations are independent of one another, this assumption does not hold when applied to studies of patent infringement litigation. There are several reasons for this: (1) many cases involve the assertion of multiple patents, decisions about these patents are made by the same judge and jury, and sometimes two or more of the patents asserted in the same case originated with the same original patent application; (2) it is common to find in a data set that the same patent has been litigated in multiple separate lawsuits against different defendants, and even though the decision makers may be different, the same patent has the same attributes in each case; and (3) some cases will be consolidated, with the same decision maker deciding certain issues-usually only pretrial summary judgments, but sometimes trial decisions as well. See John R. Allison, Mark A. Lemley, and Joshua Walker, Patent Quality and Settlement among Repeat Patent Litigants, 99 Georgetown L.J. 677, 678-79 (2011); John R. Allison and Mark A. Lemley, Empirical Evidence on the Validity of Litigated Patents, 26 AIPLA Q.J. 185, 245 (1998); Kesan and Ball, supra note _, at 261. To remedy the lack of complete independence among observations, we simultaneously clustered on the standard errors of both the unique patent numbers and the cases, because both the patents and the lawsuits were sources of observational correlation.

${ }^{66}$ We did not have enough degrees of freedom, determined by the number of observations and the number of variables, to include all thirteen of the most-used federal districts as independent variables in our logistic regression models as we had done previously, instead including only the top three districts in the regressions. We do report all thirteen of the most-used districts in the descriptive statistics, however. 
generalizable across a longer time period. The exact beginning and ending points of our data set-January 1, 2008, and December 31, 2009-are artificial cutoffs. Obviously, which suits were brought just inside and outside the time period may be due, in part, to chance. These cases are sufficiently recent, in our opinion, that the results are generally applicable today. However, there have been several legal changes in the interim that may make lawsuits today different from those in our data set. The most salient changes are the passage of the LeahySmith America Invents $\mathrm{Act}^{67}$ in 2011 (including the introduction of Inter Partes Review), the Federal Circuit's Therasense decision ${ }^{68}$ in 2011, a series of Federal Circuit decisions on venue beginning in Dec. 2008, ${ }^{69}$ and four Supreme Court cases involving the doctrine of patentable subject matter decided in 2010, ${ }^{70} 2012,{ }^{71} 2013,{ }^{72}$ and $2014 .{ }^{73}$ The Federal Circuit also issued several opinions involving patent damages, which may have affected litigant behavior and

67 Pub L No 112-29, 125 Stat 284 (2011), codified in various sections of Title 35.

68 Therasense, Inc. v Becton Dickinson and Co., 649 F3d 1276, 1296 (Fed Cir 2011) (en banc) (holding that the appropriate standard for intent to deceive is the "knowing and deliberate" standard).

69 See generally Paul R. Gugliuzza, The New Federal Circuit Mandamus, 45 Ind. L. Rev. 343 (2012) (discussing the Federal Circuit's shift in favor of granting writs of mandamus to order district courts to transfer cases to other venues).

70 Bilski v Kappos, 561 US 593, 612-13 (2010) (holding that the machine-or-transformation test is not the exclusive test for patentable material).

71 Mayo Collaborative Services v Prometheus Laboratories, Inc., 132 S Ct 1289, 1302, 1305 (2012) (setting out a two-part test for determining when a claim that includes a natural phenomenon or fact about the world is patentable).

72 Association for Molecular Pathology v Myriad Genetics, Inc., 133 S Ct 2107, 2118-19 (2013) (holding that isolated DNA is not patent eligible, because it involves a naturally occurring segment of DNA, but that synthetically created DNA is not naturally occurring and can therefore be patented).

73 Alice Corp Pty Ltd v CLS Bank International, 134 S Ct 2347 (2014) (applying the two-part Mayo test to abstract ideas in the software and business method world). 
settlement during the period of our study. ${ }^{74}$ These opinions may influence what issues litigants press and, separately, which cases reach the stage of a ruling on the merits. So too may Supreme Court decisions that change the availability of attorney's fees to prevailing defendants. ${ }^{75}$ Accordingly, the cases filed today may differ from those that we studied. And some of the cases in our data set were decided under Supreme Court and Federal Circuit opinions issued after the respective cases were filed. These subsequent legal changes may have been unforeseeable to the patent owners when they originally elected to initiate lawsuits, when the PTO originally examined the underlying patent applications, and when the patent attorneys drafted the applications. ${ }^{76}$

Second and perhaps more important, our data set contains only patents that were subject to an interim or definitive merits ruling on summary judgment, a trial, or an appeal. To be sure, we have the entire population of cases that resulted in a ruling on a dispositive motion or trial. For these cases, we report statistical results on the outcomes. However, most lawsuits settle, and as our data confirm, most lawsuits settle before any ruling on the merits. ${ }^{77}$ Cases that settled before any substantive patent ruling are completely absent from our data set.

74 See, e.g., Uniloc USA, Inc. v Microsoft Corp., 632 F3d 1292, 1315 (Fed Cir 2011) (prohibiting the use of the 25 percent rule of thumb for calculating reasonable royalties); ResQNet.com, Inc. v Lansa, Inc., 594 F3d 860, 873 (Fed Cir 2010) (vacating the district court's damages award because the reasonable royalty determination relied on speculative evidence).

75 See, e.g., Octane Fitness, LLC v Icon Health \& Fitness, Inc., 134 S Ct 1749, 1755-56 (2014).

76 See David L. Schwartz, Retroactivity at the Federal Circuit, 89 Ind. L.J. 1547, 1550 (2014) (arguing that many Federal Circuit opinions have a weak prospective effect on future patents but a strong retroactive effect on existing patents).

77 See Mark A. Lemley, Rational Ignorance at the Patent Office, 95 Nw. U. L. Rev. 1495, 1501 (2001) ("The overwhelming majority of [patent] lawsuits settle or are abandoned before trial."); Kesan and Ball, supra note _, at 271-73 (finding that the vast majority of patent cases settle). 
Moreover, many patent disputes don't result in litigation. ${ }^{78}$ Our data set lacks unlitigated disputes about patents. The upshot is that we cannot confidently generalize our data and results to the cases or disputes that settled without any substantive ruling. ${ }^{79}$ Thus, while our data shed light on who wins and loses patent cases and dispositive motions, the data cannot tell us who would win cases that are filed but settled without a judgment. ${ }^{80}$

We do not even have a sense of which direction the bias, if any, would point if one were interested in all litigated cases. Moreover, we do not know whether settled cases involving NPEs are stronger or weaker than other settled cases. For any case, whether strong or weak, settlements occur when the parties' views of the underlying merits and relative risks and costs of litigation come together. On the one hand, it may be that the cases that are settled before a merits ruling are mainly strong cases in which the parties overlapped in their expectations of success. If this were true, then the defendant win rates we observe in our data set would be higher than the win rates if all cases were litigated to judgment. On the other hand, it could be that the cases that settled before a merits ruling consist disproportionately of meritless cases

78 See Lemley, Rational Ignorance, supra note_, at 1507 (estimating that only 1.5 percent of patents are litigated, while perhaps another 5 percent are licensed without litigation).

${ }^{79}$ By comparing a random sample of patent cases that were filed in 2008-2009 but not adjudicated with the adjudicated ones in our data set, however, we do show that there is substantial, albeit imperfect, consistency across technology and industry categories between cases that were filed and settled and cases that were filed and taken to a merits decision. See infra Tables 12-14 and accompanying text.

80 Litigation and settlement incentives are extremely hard to quantify or observe. The incentives are likely influenced by many factors, including the venue of the litigation. See Allison, Lemley, and Schwartz, Understanding, supra note _, at 1793 (reporting diversity in case outcomes in patent litigation in eight distinctly busy patent districts). In our previous work, we have provided a comparison between filed lawsuits by district and our data set of adjudicated patents. Id at 1778-81. 
that were resolved via cost-of-defense settlements. ${ }^{81}$ If this alternative hypothesis were true, then our estimates of defendant win rates from the cases that reached the merits phase would be lower than the defendant win rate if all filed cases went to judgment. We do not know how, if at all, the prevalence of the foregoing types of settlements differ between NPE and non-NPE cases. Because almost all settlements are confidential, ${ }^{82}$ we cannot assess the direction of the bias of our observations relative to the population of litigated cases. We set forth in detail various selection theories and their potential effects on our results in Section IV.A.

Third, the size of our data set is relatively modest, with fewer than 1,000 patent observations. $^{83}$ This is not a sample; we report the full population of merits decisions for lawsuits filed in the years 2008 and $2009 .{ }^{84}$ However, once the data set is further broken down

81 Such claims may be common. See Mark A. Lemley and A. Douglas Melamed, Missing the Forest for the Trolls, 113 Colum. L. Rev. 2117, 2163 (2013) (stating that patent trolls pursue a large number of cases, many of which a practicing entity would probably not bring, but that these cases are more likely to settle quickly). Moreover, prior research has shown that patent owners who assert their patents many times lose more often than owners who assert patents less frequently. See Allison, Lemley, and Walker, Settlement, supra note _, at 712. We also note that we do not know the true 'value' of the patents involved in litigation. One person's 'nuisance' settlement may be, in fact, a fair settlement for the value of the patent. David L. Schwartz, The Rise of Contingent Fee Representation in Patent Litigation, 64 Ala. L. Rev. 335, 371 (2012). That said, in a large number of NPE cases settlements take the form of round numbers unrelated to the size of the defendant's business, which seems hard to square with value-based settlements. See, e.g., Eon-Net LP v. Flagstar Bancorp, 653 F.3d 1314, 1324 (Fed.Cir.2011); SFA Sys., Inc. v. Newegg, 793 F.3d 1394 (Fed. Cir .2015). Disclosure: Lemley represented Newegg in the latter case.

82 See Scott A. Moss, Illuminating Secrecy: A New Economic Analysis of Confidential Settlements, 105 Mich. L. Rev. 867, 869 (2007) ("Public settlements are the exception, common in only a few types of cases.").

${ }^{83}$ This is an unavoidable consequence of the extreme labor-intensiveness of the highly granular coding we did for every patent and every outcome.

84 Because our data set is a population, we are not merely inferring things about a population from a sample. By definition, any difference observed in a population is statistically significant. However, we generate inferential statistics in our regressions as though we were inferring things from a sample about the population from which the sample was drawn. We do this because readers may wish to extrapolate 
by technology and further still by patent law issue and procedural stage, the number of

observations in each category becomes much smaller, making statistical significance harder to find. ${ }^{85}$ We urge readers to interpret our results with these three limitations in mind.

\section{Results}

\section{A. Descriptive Statistics}

We begin by reporting the descriptive characteristics of our data set. For this paper, we focus on entity status: the reader can find much more detail about the characteristics of the litigated patents and the industries and technologies represented in our prior work.

\section{Overall Decisions}

NPEs of all types represented slightly more than a quarter of all cases in our data set (264 out of 945 decisions); the balance were brought by operating companies. The results are reported in Table 1a. This percentage may seem surprisingly low given press reports that NPEs are currently responsible for a majority of all patent assertions. Three factors help explain this

from our findings to a period of time outside the date parameters of our population, in which case our population is a sample of something larger.

85 The calculation of statistical significance does, of course, take into account the number of observations involved in a particular statistical test; the lower the number of observations, the greater the magnitude of difference there must be for a finding of statistical significance. It is important to consider the absolute and relative (to other coefficients) magnitudes of the coefficients when there is no statistical significance. The other side of this statistical coin is that it is easier to find statistical significance as the numbers of observations increase; thus, when one finds statistical significance for an independent variable that has a relatively large number of observations, It is a good idea to also look closely at the absolute and relative magnitude of the coefficient in question to determine whether the finding of statistical significance means that there is any real practical significance-that is, does the observed difference in coefficients really matter in a practical way. Thus the coefficients provide important information whether or not there is a finding of statistical significance. 
difference. First, our dataset is comprised of lawsuits filed six or seven years ago when NPEs apparently brought fewer assertions than today. According to a study of lawsuit filings by other researchers, NPEs made up less than half of both lawsuit filings and accused infringers in $2008 .{ }^{86}$ Our random sample of 2008 and 2009 filings also supports the view that operating companies brought a majority of the lawsuits in that time period. Second, our unit of measurement here is patent-case pairs, not the number of defendants sued. So a case filed by a patent plaintiff against forty defendants that results in a finding of invalidity shows up in our data set as one result, not forty. Our study ended with lawsuits filed in 2009, several years before the joinder rules were changed to require suits against separate defendants to be filed separately unless the defendants are affiliated or the assertions against them are based on the same transaction or series of transactions. Because NPEs before 2011 tended to sue more defendants in a single lawsuit than did operating companies, it is not surprising that they represent well less than half of all decisions. Third, there is reason to think that NPEs are more likely to settle their cases before decision, ${ }^{87}$ although the random sample of filed-butunadjudicated cases undercuts this reason. Settled cases do not appear in our data set.

86 Robin Feldman, Tom Ewing \& Sarah Jeruss, The AIA 500 Expanded: The Effects of Patent Monetization Entities, 17 UCLA J. \& Tech. 1, 43 (2013) (reporting that in lawsuits filed in 2008, operating companies sued $56.8 \%$ of all patent defendants).

87 See Lemley \& Melamed, supra note _, at _ (noting that some patent troll business models depend on settlement). Allison, et al found that NPEs settled at a somewhat higher rate than operating companies (90\% vs. $85 \%$ ), but the difference was not statistically significant in their smaller study. Allison et al., Patent Quality, supra note _, at _. See also, Christopher A. Cotropia, Jay P. Kesan \& David L. Schwartz, Patent Assertion Entities and Patent Litigation Characteristics and Outcomes (draft) (finding some differences in settlement rates among various types of entities). 
Table 1a

Entire Population-Operating Co. vs. NPE

\begin{tabular}{|l|l|l|}
\hline & Frequency & Percent \\
\hline $\begin{array}{l}\text { Operating } \\
\text { Company }\end{array}$ & 681 & 72.1 \\
\hline NPE & 264 & 27.9 \\
\hline Total & 945 & 100.0 \\
\hline
\end{tabular}

Figure 1

Entire Population-Operating Co. vs. NPE

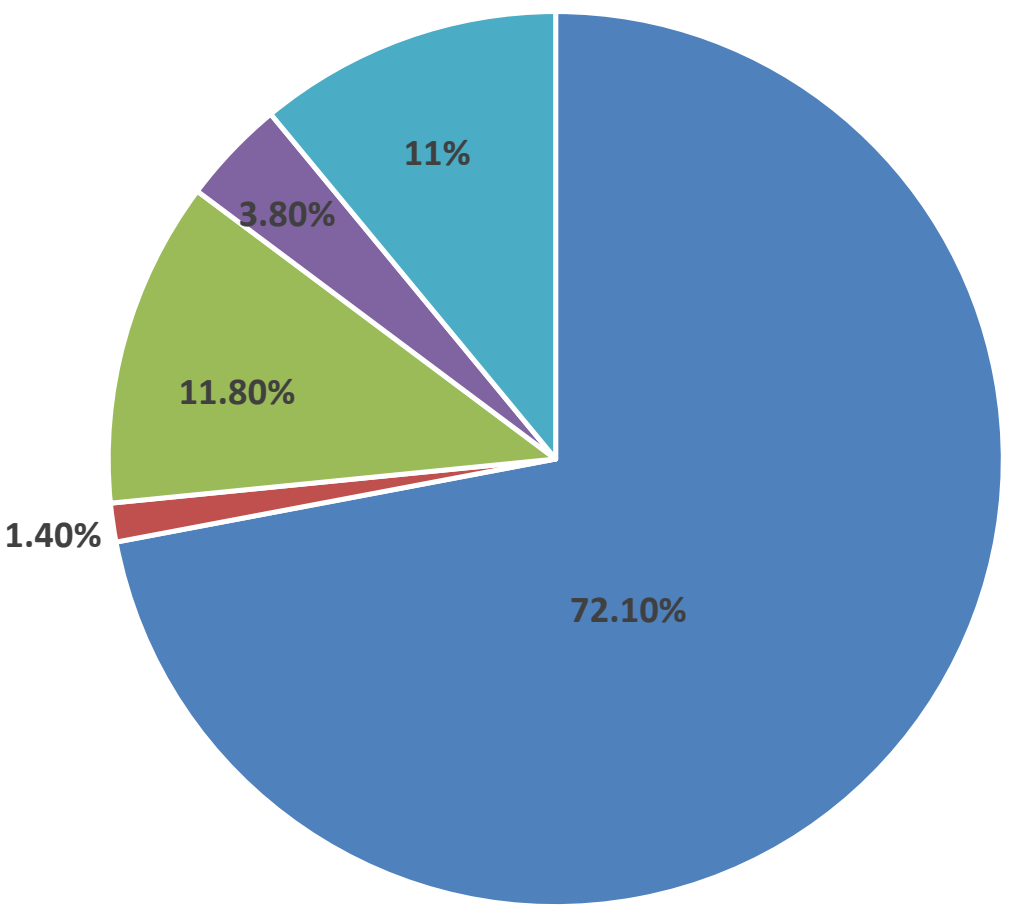

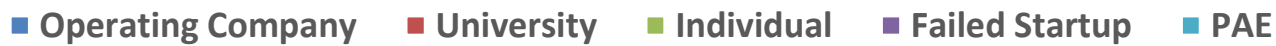


In Figure 1 we break down the NPEs into their component groups. ${ }^{88}$ Individuals and PAEs make up the bulk of all NPE cases in our data set, together accounting for 215 of the 264 NPEs, or $81.4 \%$. The remainder are mostly failed startups; universities accounted for only 13 cases in our data set.

\section{Forum Selection}

We find major differences between operating companies and NPEs in the federal districts in which the lawsuits were filed and decided. We identify each of the thirteen judicial districts with the most patent cases. The differences for the top four districts are reported in Table 2a, which lists the number and percentage of decisions for operating companies and NPEs in each district. Table $2 \mathrm{~b}$ does the same thing, but with NPEs separated into their subtypes. The differences for the full thirteen districts are reported in the Appendix. The tables comparing operating companies with a broad NPE category also indicate in the far right-hand column a pvalue showing whether the observed differences in percentages (proportions) by district, when sorted by entity type, are statistically significant when compared with the difference in percentages among districts overall. ${ }^{89}$ For tables with NPEs separated into their subtypes, we

\footnotetext{
${ }^{88}$ Table $\mathrm{A} 1$ in the Appendix provides the raw counts of each group.

89 This was done by conducting an "equality of proportions" test, in which the null hypothesis is that the proportions attributable to each entity type are equal. If at least one of the proportions is not equal to the others at a confidence level of $95 \%$ or more-a $p$-value of $<0.05-$ we can say that the finding of inequality is not due to chance with that level of confidence. In subsequent tables showing descriptive statistics, the Fisher's Exact tests (used when numbers of observations are small) for equality of proportions will be the same-are the observed differences in percentages among districts, technologies, or industries, when sorted by entity type, statistically significant when compared with the proportions among districts, technologies, or industries overall (without sorting by entity type).
} 
compared each subtype to an operating company category, and noted statistically significant results in the table itself by the use of asterisks. ${ }^{90}$

The Eastern District of Texas decided a disproportionate number of NPE cases. From other sources, we know that a substantial percentage of the lawsuits filed in the Eastern District of Texas are NPE cases. ${ }^{91}$ While $13.4 \%$ of all patent decisions in the country are made by the Eastern District of Texas, that court decided only $8.2 \%$ of the operating company cases but more than one-quarter (26.9\%) of NPE cases. Indeed, a substantial majority of all the patent cases decided in the Eastern District of Texas were NPE cases. The odds against that being a random effect are quite small $(p<0.001)$. Three other districts have a greater than proportionate share of NPE decisions: the Central District of California, which accounted for only $5.9 \%$ of all decisions but $9.1 \%$ of NPE decisions, and the Northern District of Illinois, with $4.2 \%$ of all decisions but $8.7 \%$ of NPE decisions. ${ }^{92}$ Every other district, including the popular District of Delaware, representing almost as many decisions as the Eastern District of Texas, disproportionately decided operating company rather than NPE cases. ${ }^{93}$ In three cases the disproportion was striking: the Southern District of New York had only $1.9 \%$ of the NPE

\footnotetext{
${ }^{90}$ In each regression, we employ a null hypothesis of "no difference." If we are able to reject the null hypothesis, this means that we can, with a particular degree of confidence, assert that the observed difference is not due to chance. In this paper, we use the following scheme for denoting $p$-values: ${ }^{*}=p$ $<0.05 ;^{* *}=p<0.01 ;^{* * *}=p<0.0001$. A $p$-value of less than 0.05 means that one can say with something over $95 \%$ confidence that the difference we observe is not due to random chance. A p-value of $<0.01$ means that we can do this with at least $99 \%$ confidence, and $p=<0.001$ means a confidence level of over $99.9 \%$.

91 See Cotropia et al, supra note

92 The final district was the Northern District of Ohio, which had $1.8 \%$ of all decisions but $2.7 \%$ of NPE decisions. But the difference was only statistically significant at the $90 \%$ confidence level (Fisher's exact p-value $=0.074$ ).

93 In the case of Delaware, however, the difference was significant only at the $90 \%$ confidence level $(p=0.090)$.
} 
decisions but $6.2 \%$ of the practicing entity decisions, and the Western District of Wisconsin had only $1.1 \%$ of the NPE decisions but $3.7 \%$ of the practicing entity decisions. ${ }^{94}$

Table 2a

Observations by District

Proportions Among Top 4 Districts by Entity Type Compared with Overall District Proportions Operating Companies vs. Broad NPE

\begin{tabular}{|l|l|l|l|l|}
\hline $\begin{array}{l}\text { Top Row } \\
\text { Frequency; } \\
\text { Bottom Row }=\end{array}$ & & & & \\
$\begin{array}{l}\text { Percentage } \\
*=p<0.05 ; * * \\
p<0.01 ; * * * \\
0.001\end{array}$ & $\begin{array}{l}\text { Operating } \\
\text { Company }\end{array}$ & Broad_NPE & Total & $\begin{array}{l}\text { Comp. of } \\
\text { proportions } \\
\text { (Fisher's Exact } \\
\text { test) p-value }\end{array}$ \\
\hline TX ED & 56 & 71 & 127 & \\
\hline & $8.2 \%$ & $26.9 \%$ & & $<0.001^{* * *}$ \\
\hline D ED & 101 & 21 & 122 & \\
\hline & $14.8 \%$ & $8.0 \%$ & & $0.005^{* *}$ \\
\hline CA ND & 64 & 17 & 81 & \\
\hline & $9.4 \%$ & $6.4 \%$ & & 0.156 \\
\hline CA CD & 32 & 24 & 56 & \\
\hline & $4.7 \%$ & $9.1 \%$ & & $0.014^{*}$ \\
\hline
\end{tabular}

94 The final district was the Southern District of Texas, which accounted for $0.8 \%$ of NPE decisions but $2.9 \%$ of operating company decisions. 
Table 2b

Observations by District

Proportions Among Top 4 Districts by Entity Type Compared with Overall District Proportions Operating Companies vs. NPE Subtypes

\begin{tabular}{|c|c|c|c|c|c|c|}
\hline $\begin{array}{l}\text { Top Row = } \\
\text { Frequency; } \\
\text { Bottom Row = } \\
\text { Percentage } \\
*=\mathrm{p}<0.05 ; * * \\
=\mathrm{p}<0.01 ; \\
=\mathrm{p}<0.001\end{array}$ & $\begin{array}{l}\text { Operating } \\
\text { Company }\end{array}$ & University & Individual & $\begin{array}{l}\text { Failed } \\
\text { Startup }\end{array}$ & PAE & Total \\
\hline \multirow[t]{2}{*}{ TX ED } & 56 & 1 & 29 & 14 & 27 & 127 \\
\hline & $8.2 \%$ & $7.7 \%$ & $26.1 \% * *$ & $38.9 \% * *$ & $26.0 \% * *$ & \\
\hline \multirow[t]{2}{*}{ D ED } & 101 & 0 & 2 & 5 & 14 & 122 \\
\hline & $14.8 \%$ & $0.0 \%$ & $1.8 \% * *$ & $13.9 \%$ & $13.5 \%$ & \\
\hline \multirow[t]{2}{*}{ CA ND } & 64 & 1 & 3 & 1 & 12 & 81 \\
\hline & $9.4 \%$ & $7.7 \%$ & $2.7 \% *$ & $2.8 \%$ & $11.5 \%$ & \\
\hline \multirow[t]{2}{*}{ CA CD } & 32 & 0 & 11 & 2 & 11 & 56 \\
\hline & $4.7 \%$ & $0.0 \%$ & $9.9 \% *$ & $5.6 \%$ & $10.6 \% *$ & \\
\hline
\end{tabular}

When we separate the larger class of NPEs into constituent subgroups, we find that university suits follow a different pattern than other NPEs. No district had more than one decided university case. While we counsel caution because there are only 13 university patents spread across 8 lawsuits, this finding is likely a function not only of the small number of university cases in our data set but also the fact that universities tend to file suit where they are located and may settle or press cases for different reasons than other parties; only $27.8 \%$ of overall patent decisions were outside the top 13 districts, but $69.2 \%$ of university patent decisions were.

Excluding universities, the Eastern District of Texas remained quite popular in deciding disputes involving all other types of NPEs. Failed start-ups in particular were likely to have their patents ruled upon there; $38.9 \%$ of failed startup decisions nationwide were in the Eastern 
District of Texas. But both individuals and PAEs litigated more than a quarter of their nationwide decisions in the Eastern District of Texas, compared to only $8.2 \%$ of operating companies. The District of Delaware is noted for the paucity of cases brought by individuals; only $1.8 \%$ were adjudicated there, compared with $12.9 \%$ overall. Once universities and individuals are discounted, Delaware proved about as popular with PAEs and failed startups as with operating companies; they each had decided about the same percentage of cases there. ${ }^{95}$ One other interesting finding is that several districts in the Northeast with substantial numbers of patent cases - the District of Massachusetts, the District of New Jersey, and the Southern District of New York - had no PAE decisions at all in our data set. By contrast, the Northern District of California, often considered a pro-defense jurisdiction, actually had a higher percentage of PAE cases (11.5\% of those decided nationwide) than of operating company cases 9.4\%). ${ }^{96}$ With our data, we cannot say whether this is because of initial lawsuit filings or settlement behavior. ${ }^{97}$

95 Each of these differences is significant (ED Texas $p=0.001$; Delaware $p=0.039$ ).

96 Our cases include both plaintiff-filed suits and declaratory judgment actions, and some of those results may represent declaratory judgment claims filed against PAEs in the Northern District of California.

Interestingly, however, we find that accused infringers are not significantly more likely to file declaratory judgment actions against NPEs than against operating companies in the cases that went to judgment. Table 3 a reports the number and percentage of cases in which declaratory judgment actions were filed and adjudicated against operating companies and NPEs as a whole, and Table $3 \mathrm{~b}$ reports the numbers and percentages of DJ cases brought and decided against operating companies and the several NPE subtypes. Accord Risch, Generation, supra note at 98 . 
Finally, we note that all other districts combined showed no significant variation in the proportion of entity types. To the extent different entities are engaged in forum selection, it appears to be focused on the most popular districts.

\section{Technology and Industry}

We find very substantial differences between operating company and NPE adjudicated suits by technology and industry area. More than a third of all operating company decisions involved mechanical patents, while less than one in seven NPE cases did $34.51 \%$ of operating

Table 3a

Declaratory Judgments

Proportions Between Entity Types Compared with Overall Entity Proportions Operating Companies vs. NPE Subtypes

\begin{tabular}{|l|l|l|l|l|l|}
\hline $\begin{array}{l}\text { Top Row } \\
\begin{array}{l}\text { Frequency; } \\
\text { Bottom Row } \\
\text { Percentage }\end{array}\end{array} \quad \begin{array}{l}\text { Operating } \\
\text { Company }\end{array}$ & NPE & Total & $\begin{array}{l}\text { Comp. } \\
\text { proportions } \\
\text { Fisher's Exact Test } \\
\text { p-value }\end{array}$ \\
\hline $\begin{array}{l}\text { Declaratory } \\
\text { Judgments }\end{array}$ & 62 & 24 & 86 & & \\
\hline & $9.1 \%$ & $9.1 \%$ & & & $>0.999$ \\
\hline
\end{tabular}

Table 3b

Declaratory Judgments

Proportions Among Entity Types Compared with Overall Entity Proportions Operating Companies vs. NPE Subtypes

\begin{tabular}{|l|l|l|l|l|l|l|}
\hline $\begin{array}{l}\text { Top Row } \\
\begin{array}{l}\text { Frequency; } \\
\text { Bottom Row } \\
\text { Percentage }\end{array}\end{array}$ & $\begin{array}{l}\text { Operating } \\
\text { Company }\end{array}$ & University & Individual & $\begin{array}{l}\text { Failed } \\
\text { Startup }\end{array}$ & PAE & Total \\
\hline $\begin{array}{l}\text { Declaratory } \\
\text { Judgments }\end{array}$ & 62 & 0 & 11 & 4 & 9 & 86 \\
\hline & $9.1 \%$ & $0.0 \%$ & $9.9 \%$ & $11.1 \%$ & $8.7 \%$ & \\
\hline
\end{tabular}

${ }^{97}$ We did not capture information about cases transferred from one venue to another. We treated each case as adjudicated in the venue that ruled upon the merits issue. 
company suits vs. $13.6 \%$ of NPE suits). Over $1 / 5$ (21.9\%) of operating company suits involved chemistry patents, while only $1.9 \%$ of NPE cases did. The biggest difference was in software: 22.8\% of operating company cases litigated to judgment involved software patents, while a whopping $65.9 \%$ of NPE suits did. ${ }^{98}$ The differences in likelihood of NPE assertion by technology in mechanical, chemical, biotechnology, and overall software are all statistically significant. We present the results in Figures 2 and 3, with additional details provided in Tables A4 and A5 in the Appendix.

Figure 2

\section{Percentage of Observations by Primary Technology} Operating Company vs. NPE

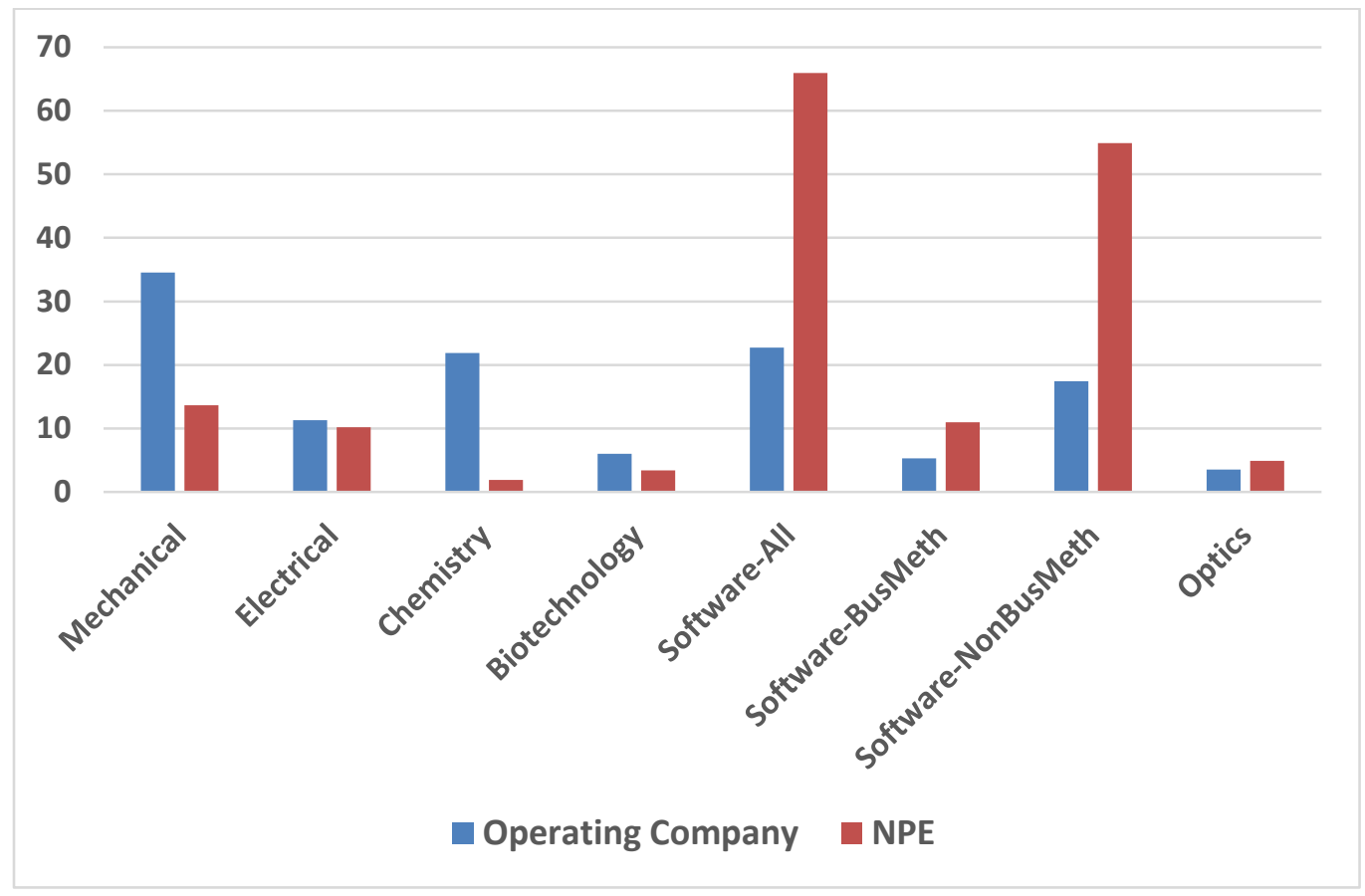

98 We report here only the results for categorizing each patent into one primary, mutually-exclusive technology category. We ran an alternative specification in which those patents also covering a secondary but still integral technology category were assigned to one or more secondary technology fields. Approximately $30 \%$ of the patents in our data set covered at least one secondary technology area. This alternative approach better captures the nuance of certain technologies, but does so at the cost of abandoning mutually-exclusive technology categories. The results were largely similar to what we describe in text for primary technology areas alone. 


\section{Figure 3 \\ Percentages of Observations by Primary Technology ${ }^{99}$ \\ Operating Company vs. NPE Subtypes}

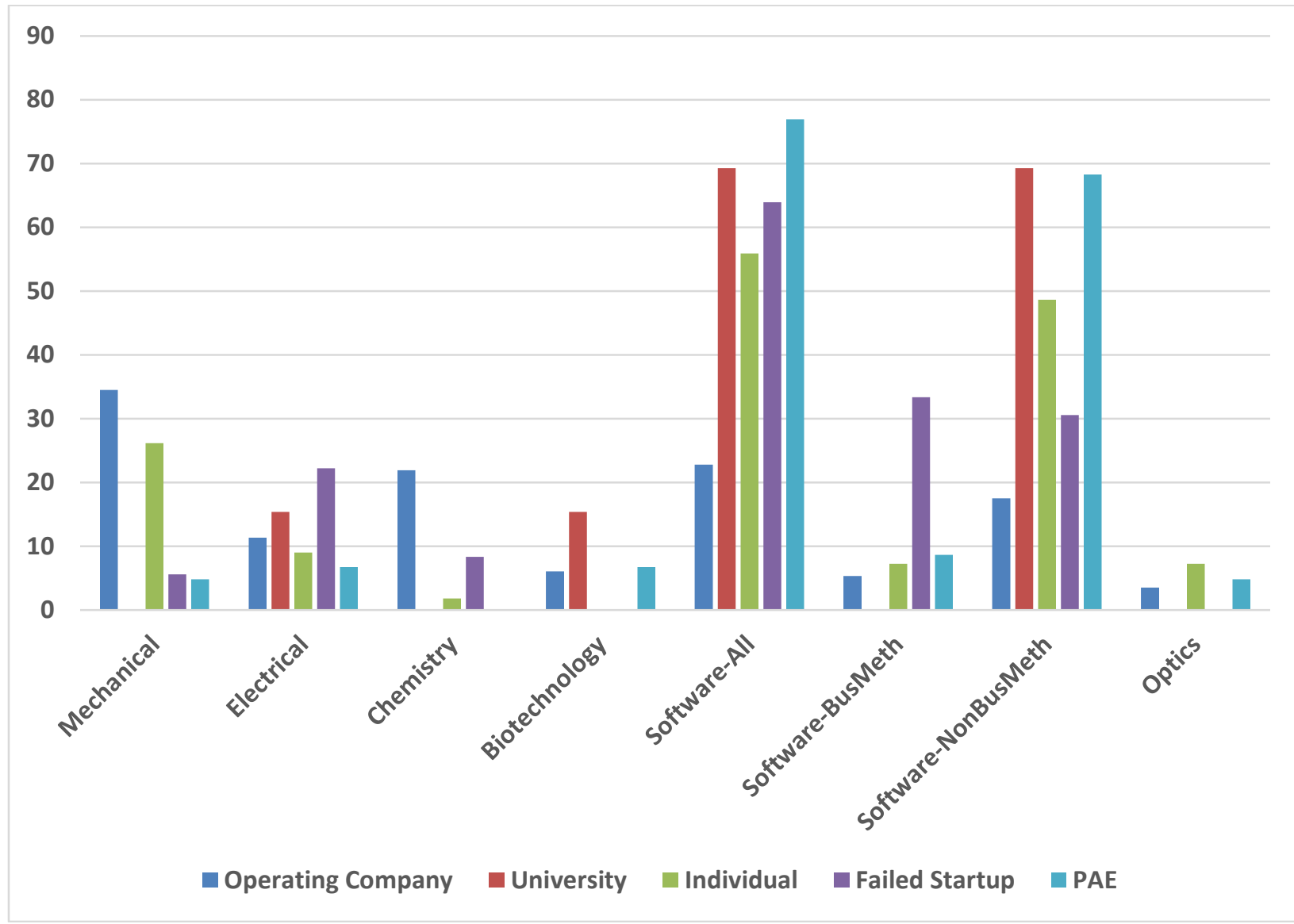

Breaking those numbers down by type of NPE reveals some interesting facts. Every type of NPE decision, including universities, was heavily focused on software patents; software and business method patents constituted a majority of decisions for every type of NPE. PAEs had $76.9 \%$ of their decisions in software, while universities, generally thought to be more active in

99 The bar represents the percentage of suits brought by a particular entity type that are in the listed technology. The categories are mutually exclusive, except that "software-all" is a sum of "softwarebusiness methods" and "software-non business methods." 
the life sciences, were close behind with $69.2 \%$ of their decided cases involving software. ${ }^{100}$ PAEs were not heavily invested in mechanical (only $4.8 \%$ of their decisions) or electrical patent litigation (only 6.7\%) in our data set, and they were not involved in a single chemistry case decided in our data set. To our surprise, however, and contrary to conventional wisdom, PAEs did play a significant role in biotechnology litigation. Biotechnology actually represents a slightly higher percentage of PAE suits that reached a merits ruling (6.7\%) than it does of operating company suits (6.0\%), though most biotechnology decisions, like most decisions of all types, involved operating company plaintiffs. ${ }^{101}$

Figure $4^{102}$ and Table 5 tell a somewhat similar, if less dramatic, story by industry affected. $^{103}$ Software patents are scattered through various industries, but NPEs have an outsized influence in the computer and electronics industries (accounting for $27.7 \%$ of NPE decisions but only $8.2 \%$ of operating company decisions) and the communications industry (accounting for $20.5 \%$ of NPE decisions but only $10.1 \%$ of operating company cases). Breaking down the NPEs into subtypes reveals that PAEs are even more overrepresented in those industries, with computer and electronics accounting for $35.6 \%$ of PAE suits which reached a

100 While universities are generally thought of as patenting primarily in the life sciences, one of the authors has previously identified this trend of increased university activity in both patenting and litigating in the software space. John R. Allison, Arti K. Rai, \& Bhaven Sampat, University Software Ownership and Litigation: A First Examination, 87 N.C. L. Rev. 1519 (2009).

101 Robin Feldman \& W. Nicholson Price II, Patent Trolling: Why Bio and Pharmaceuticals Are At Risk, http://papers.ssrn.com/sol3/papers.cfm?abstract id=2395987 (arguing that university patents in the life sciences may be attractive to "trolls").

${ }^{102}$ Table 5 provides the underlying data used to generate Figure 4.

103 We explain the difference between technology and industry classifications in detail in our prior paper. Allison et al., Divided, supra note _, at _. Technology categories reflect the nature of the invention itself, while industry categories reflect the market in which that invention is deployed. 
merits ruling and communications for $23.1 \%$. Operating companies, by contrast, are far more prevalent in the pharmaceutical, medical device, and energy industries.

Figure 4

Proportions Among Industries by Entity Type Compared with Overall Industry Proportions Operating Companies vs. NPE

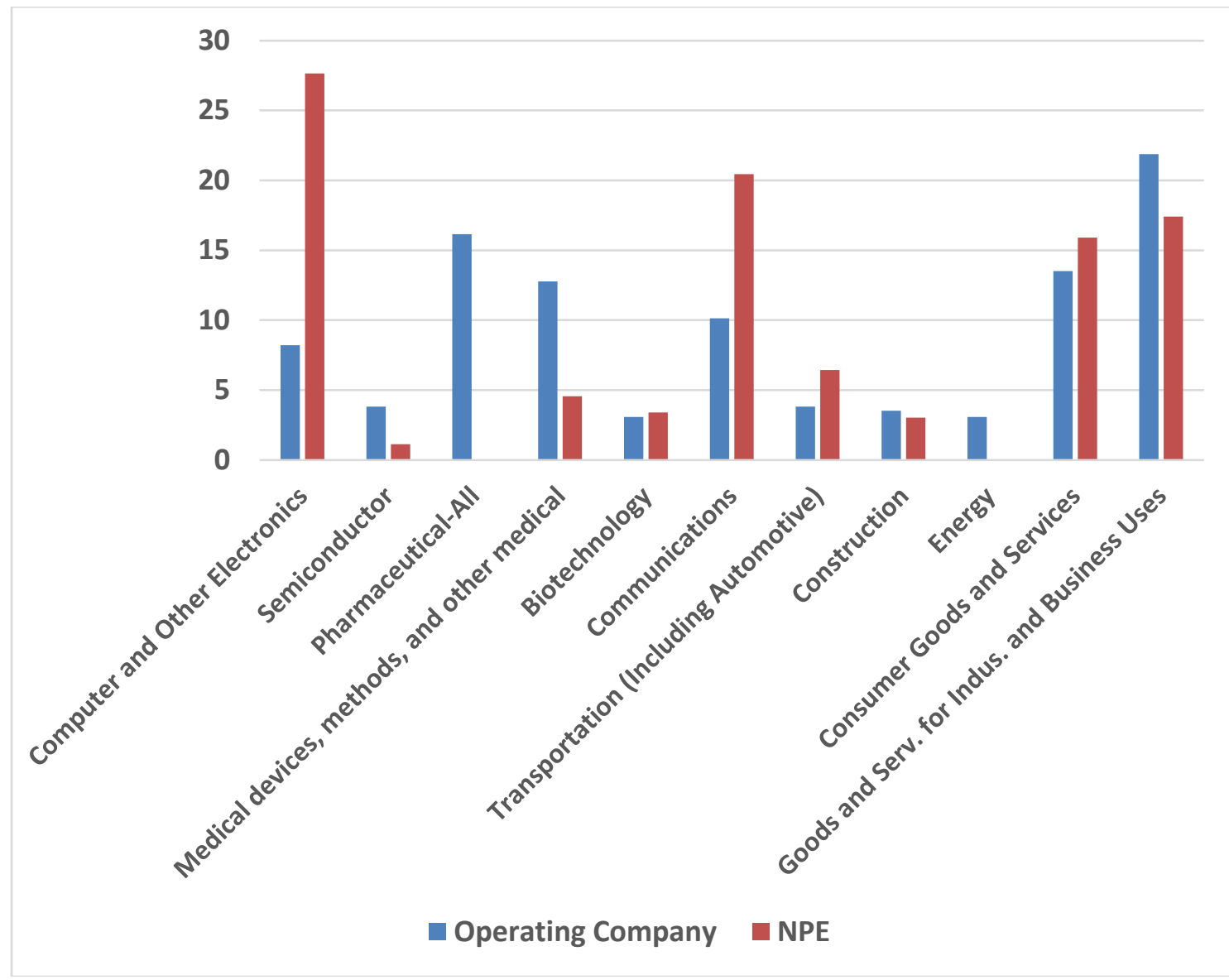


Table 5

Proportions Among Industries by Entity Type Compared with Overall Industry Proportions Operating Companies vs. NPE Subtypes

\begin{tabular}{|c|c|c|c|c|c|c|}
\hline $\begin{array}{l}\text { Top Row = Frequency; } \\
\text { Bottom Row = } \\
\text { Percentage } \\
*=\mathrm{p}<0.05 ; * *=\mathrm{p}< \\
0.01 ; * * *=\mathrm{p}<0.001\end{array}$ & $\begin{array}{l}\text { Operating } \\
\text { Company }\end{array}$ & University & Individual & $\begin{array}{l}\text { Failed } \\
\text { Startup } \\
\end{array}$ & PAE & Total \\
\hline \multirow[t]{2}{*}{$\begin{array}{l}\text { Computer and Other } \\
\text { Electronics }\end{array}$} & 56 & 5 & 21 & 10 & 37 & 129 \\
\hline & $8.2 \%$ & $38.5 \% * *$ & $18.9 \% * *$ & $27.8 \% * *$ & $35.6 \% * *$ & \\
\hline \multirow[t]{2}{*}{ Semiconductor } & 26 & 2 & 1 & 0 & 0 & 29 \\
\hline & $3.8 \%$ & $15.4 \%$ & $0.9 \%$ & $0.0 \%$ & $0.0 \% *$ & \\
\hline \multirow[t]{2}{*}{ Pharmaceutical } & 110 & 0 & 0 & 0 & 0 & 110 \\
\hline & $16.2 \%$ & $0.0 \% * *$ & $0.0 \% * *$ & $0.0 \% * *$ & $0.0 \%$ & \\
\hline \multirow[t]{2}{*}{ ANDA case } & 101 & 0 & 0 & 0 & 0 & 101 \\
\hline & $14.8 \%$ & $0.0 \%$ & $0.0 \% * *$ & $0.0 \% * *$ & $0.0 \% * *$ & \\
\hline \multirow[t]{2}{*}{$\begin{array}{l}\text { Medical devices, } \\
\text { methods, and other } \\
\text { medical }\end{array}$} & 87 & 3 & 7 & 2 & 0 & 99 \\
\hline & $12.8 \%$ & $23.1 \%$ & $6.3 \%$ & $5.6 \%$ & $0.0 \% * *$ & \\
\hline \multirow[t]{2}{*}{ Biotechnology } & 21 & 2 & 0 & 0 & 7 & 30 \\
\hline & $3.1 \%$ & $15.4 \%$ & $0.0 \%$ & $0.0 \%$ & $6.7 \%$ & \\
\hline \multirow[t]{2}{*}{ Communications } & 69 & 1 & 21 & 8 & 24 & 123 \\
\hline & $10.1 \%$ & $7.7 \%$ & $18.9 \% * *$ & $22.2 \% *$ & $23.1 \% * *$ & \\
\hline \multirow[t]{2}{*}{$\begin{array}{l}\text { Transportation } \\
\text { (Including Automotive) }\end{array}$} & 26 & 0 & 14 & 0 & 3 & 43 \\
\hline & $3.8 \%$ & $0.0 \%$ & $12.6 \% * *$ & $0.0 \%$ & $2.9 \%$ & \\
\hline \multirow[t]{2}{*}{ Construction } & 24 & 0 & 8 & 0 & 0 & 32 \\
\hline & $3.5 \%$ & $0.0 \%$ & $7.2 \%$ & $0.0 \%$ & $0.0 \%$ & \\
\hline \multirow[t]{2}{*}{ Energy } & 21 & 0 & 0 & 0 & 0 & 21 \\
\hline & $3.1 \%$ & $0.0 \%$ & $0.0 \%$ & $0.0 \%$ & $0.0 \%$ & \\
\hline \multirow[t]{2}{*}{$\begin{array}{l}\text { Consumer Goods and } \\
\text { Services }\end{array}$} & 92 & 0 & 15 & 8 & 19 & 134 \\
\hline & $13.5 \%$ & $0.0 \%$ & $13.5 \%$ & $22.2 \%$ & $18.3 \%$ & \\
\hline \multirow[t]{2}{*}{$\begin{array}{l}\text { Goods and Serv. for } \\
\text { Indus. and Business } \\
\text { Uses }\end{array}$} & 149 & 0 & 24 & 8 & 14 & 195 \\
\hline & $21.9 \%$ & 0 & $21.6 \%$ & $22.2 \%$ & $13.5 \%$ & \\
\hline Total & 782 & 13 & 111 & 36 & 104 & 1046 \\
\hline
\end{tabular}


These descriptive results largely confirm conventional wisdom about NPE behavior. The Eastern District of Texas disproportionately decides NPE lawsuits, and especially those brought by PAEs. Adjudicated PAE lawsuits overwhelmingly involve software patents. Other results are more surprising, however, including the software-heavy nature of university patent adjudications (although admittedly the number of observations is very small) and the presence of PAEs in the biotechnology industry.

\section{B. Litigation Outcomes}

Operating companies won more often than NPEs in our data set. We report the results in Tables $6 a$ and $6 \mathrm{~b}$ for four litigation outcomes, first by operating companies vs. NPEs and then by operating companies vs. the NPE subtypes. Following Tables $6 a$ and $6 \mathrm{~b}$ we present bar graphs showing "patentee definitive wins"104 by operating companies vs. NPE and by operating companies vs. NPE subtypes. We provide results from thirteen additional litigation outcomes in the Appendix in Tables A6 and A7.

The overall definitive patentee win rate in our data set among cases that went to a final judgment is $25.8 \%$, which is consistent with prior work showing that patentees win approximately a quarter of their cases. ${ }^{105}$ When we break that number down into operating

${ }^{104}$ A "definitive win" by a patent owner occurred when the patent owner received a favorable final judgment on all infringement and validity issues that were contested in the case.

105 Allison et al., Understanding, supra note _; Paul M. Janicke \& LiLan Ren, Who Wins Patent Infringement Cases?, 34 AIPLA Q.J. 1 (2006) (finding a 26\% overall win rate ten years ago). It is interesting that the win rate was essentially the same in 2008-2009 as it was ten years ago, given the large increase in PAE litigation in this time frame and other changes to the patent law in the interim. 
companies and NPEs and do not control for industry or technology, we find that operating companies' success rate in adjudicated cases more than twice as high $-30.6 \%$ of definitive patent rulings involving operating companies resulted in a win for the patentee, compared with only $14.4 \%$ of NPE rulings. That difference is statistically significant at a high level of confidence. NPEs did worse than operating companies in our dataset on most of the outcomes; however, the differences between NPEs and operating companies on several litigated issues were not statistically significant, including notably grants of summary judgment of noninfringement. As for statistically significant results, as described in the Appendix, we found invalidity based on claim indefiniteness (found $10.5 \%$ of the time it was ruled upon against operating companies but $31.7 \%$ of the time against NPEs), invalidity based on inadequate disclosure (found $16.8 \%$ of the time it was ruled upon against operating companies but $75 \%$ of the time against NPEs), and inducing and contributory infringement.

See Mark A. Lemley, The Surprising Resilience of the Patent System (working paper 2016) (making this point). One of the authors has explained the low patentee win rate as a function of the structure of patent litigation, in which winning on even one issue is usually enough for an accused infringer to defeat a suit, while the patentee must prevail on every issue in order to win. Mark A. Lemley, The Fractioning of Patent Law, in Intellectual Property and the Common Law 504 (Shyamkrishna Balganesh ed. 2013). Consistent with that hypothesis, patentees of all stripes do much better in interim rulings (such as denials of summary judgment) than they do in final rulings. 
Table $6 a$

Litigation Outcomes Compared Between Entity Types

Operating Companies vs. NPE

\begin{tabular}{|c|c|c|c|c|}
\hline $\begin{array}{l}\text { Top Row = Frequency; } \\
\text { Bottom Row = } \\
\text { Percentage } \\
*=\mathrm{p}<0.05 ; * *=\mathrm{p}< \\
0.01 ; * * *=\mathrm{p}<0.001\end{array}$ & $\begin{array}{l}\text { Operating } \\
\text { Company }\end{array}$ & NPE & Total & $\begin{array}{l}\text { Comp. of proportions } \\
\text { (Fisher's Exact test) p- } \\
\text { value }\end{array}$ \\
\hline $\begin{array}{l}\text { Patent Owner Interim } \\
\text { Winner }\end{array}$ & 222 & 69 & 291 & \\
\hline \multirow[t]{2}{*}{$\begin{array}{l}\text { Patent Owner } \\
\text { Definitive Winner }\end{array}$} & 136 & 27 & 163 & \\
\hline & $30.6 \%$ & $14.4 \%$ & & $<0.001 * * *$ \\
\hline \multirow[t]{2}{*}{$\begin{array}{l}\text { SJ Invalidity-All } \\
\text { Grounds }\end{array}$} & 87 & 44 & 131 & \\
\hline & $26.9 \%$ & $42.3 \%$ & & $0.005^{* *}$ \\
\hline \multirow[t]{2}{*}{ SJ of Noninfringement } & 172 & 83 & 255 & \\
\hline & $51.8 \%$ & $59.7 \%$ & & 0.129 \\
\hline $\begin{array}{l}\text { Total Direct } \\
\text { Infringement-Any } \\
\text { Stage }\end{array}$ & 160 & 37 & 197 & \\
\hline & $42.4 \%$ & $22.4 \%$ & & $<0.001 * * *$ \\
\hline \multirow[t]{2}{*}{$\begin{array}{lll}\text { Patent } & \text { Owner } & \text { Trial } \\
\text { Winner } & & \\
\end{array}$} & 142 & 33 & 175 & \\
\hline & $60.9 \%$ & $60.0 \%$ & & 1.000 \\
\hline
\end{tabular}


Figure 5

Patent Owner Definitive Winner

Operating Companies vs. NPE

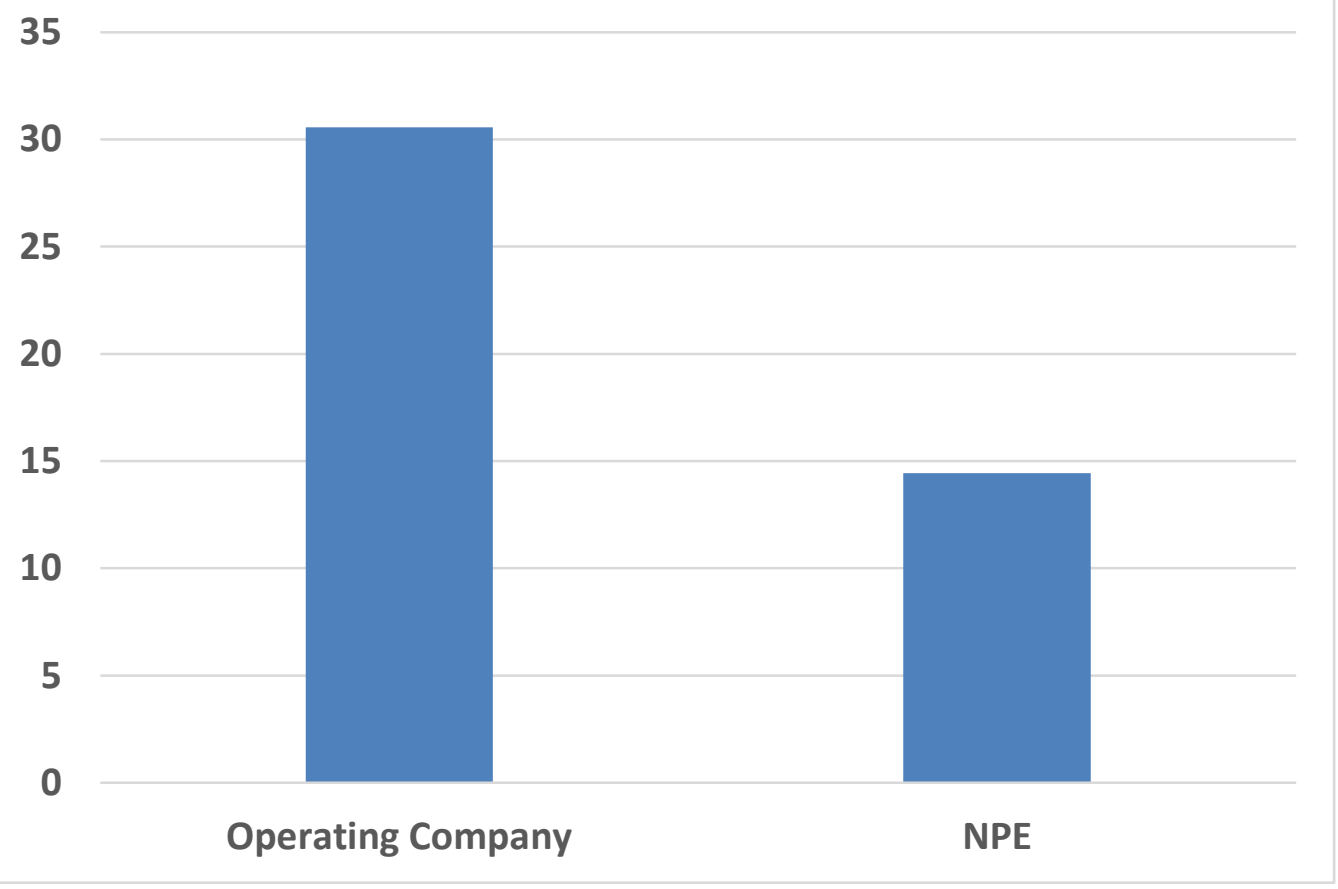


Table 6b

\section{Litigation Outcomes Compared Among Entity Types Operating Companies vs. NPE Subtypes}

\begin{tabular}{|c|c|c|c|c|c|c|}
\hline $\begin{array}{l}\text { Top Row = Frequency; } \\
\text { Bottom Row } \\
\text { Percentage } \\
*=\mathrm{p}<0.05 ; * *=\mathrm{p}< \\
0.01 ; * * *=\mathrm{p}<0.001\end{array}$ & $\begin{array}{l}\text { Operating } \\
\text { Company }\end{array}$ & University & Individual & $\begin{array}{l}\text { Failed } \\
\text { Startup }\end{array}$ & PAE & Total \\
\hline $\begin{array}{l}\text { Patent Owner Interim } \\
\text { Winner }\end{array}$ & 222 & 2 & 35 & 8 & 24 & 291 \\
\hline $\begin{array}{l}\text { Patent Owner Definitive } \\
\text { Winner }\end{array}$ & 136 & 3 & 11 & 6 & 7 & 163 \\
\hline & $30.6 \%$ & $30.0 \%$ & $14.7 \% * *$ & $21.4 \%$ & $9.5 \% * *$ & \\
\hline $\begin{array}{l}\text { Patent Owner } \\
\text { Winner }{ }^{2}+\text { Interim } \\
\text { Winner }^{106}\end{array}$ & 358 & 5 & 46 & 14 & 31 & 454 \\
\hline & 52.6 & 38.5 & $41.4^{* *}$ & 38.9 & $29.8 * *$ & \\
\hline $\begin{array}{ll}\text { SJ Invalidity-All } \\
\text { Grounds }\end{array}$ & 87 & 0 & 23 & 7 & 14 & 131 \\
\hline & $26.9 \%$ & $0.0 \%$ & $41.8 \% *$ & $50.0 \%$ & $50.0 \% *$ & \\
\hline SJ of Noninfringement & 172 & 3 & 38 & 9 & 33 & 255 \\
\hline
\end{tabular}

${ }^{106}$ Here, we count all definitive and interim wins for the patentee in our dataset. Interim wins are cases without either party winning in full on the merits, such as cases with summary judgment being denied. Most interim wins in our dataset were patentee interim wins - denials of summary judgment followed by a settlement. Some were coded as accused infringer interim wins, such as a grant of summary judgment of no literal infringement coupled with a denied of summary judgment of no infringement under the doctrine of equivalents. The foregoing example is ambiguous as to which party prevailed. While the accused infringer has narrowed the case, it did not narrow it as much as it sought. It may have substantially improved its litigation position, reducing the value of the case to near zero. Or it may have not materially improved its position at all, since it must face a jury on the infringement allegation. Other accused-infringer interim wins are less ambiguous, as when a patentee moves for summary judgment on an inequitable conduct defense and that motion is denied. In Table 6b, we count what we coded as accused infringer interim wins as patentee losses. However, some may view it as more appropriate to count what we coded as accused infringer interim wins as patentee wins. If one were to presume that all settlements involve some payment to the patentee, one would add all interim wins to patentee definitive wins. If we so count, the results are largely the same as the results reported in the above table. Operating companies prevail $54.6 \%$ (372) of the time, universities $46.2 \%$ (6), individuals $42.3 \%$ (47), failed start-ups $38.9 \%$ (14), and PAEs 35.6\% (37). But it may well be that many or even most of the cases that were settled or dropped after an interim ruling were dismissed without a payment, in which case none of them should be included. The short answer is that there is no way to tell what happened in a confidential settlement. 


\begin{tabular}{|l|l|l|l|l|l|l|} 
& $51.8 \%$ & $42.9 \%$ & $63.3 \%$ & $47.4 \%$ & $62.3 \%$ & \\
\hline $\begin{array}{l}\text { Total Direct } \\
\text { Infringement-Any Stage }\end{array}$ & 160 & 3 & 16 & 6 & 12 & 197 \\
\hline & $42.4 \%$ & $30.0 \%$ & $29.6 \%$ & $25.0 \%$ & $15.6 \% * *$ & \\
\hline $\begin{array}{l}\text { Patent Owner Trial } \\
\text { Winner }\end{array}$ & 142 & 3 & 12 & 10 & 8 & 175 \\
\hline & $60.9 \%$ & $100.0 \%$ & $37.0 \%$ & $85.7 \%$ & $72.6 \%$ & \\
\hline
\end{tabular}

Figure 6

Patent Owner Definitive Winner

Operating Companies vs. NPE Subtypes

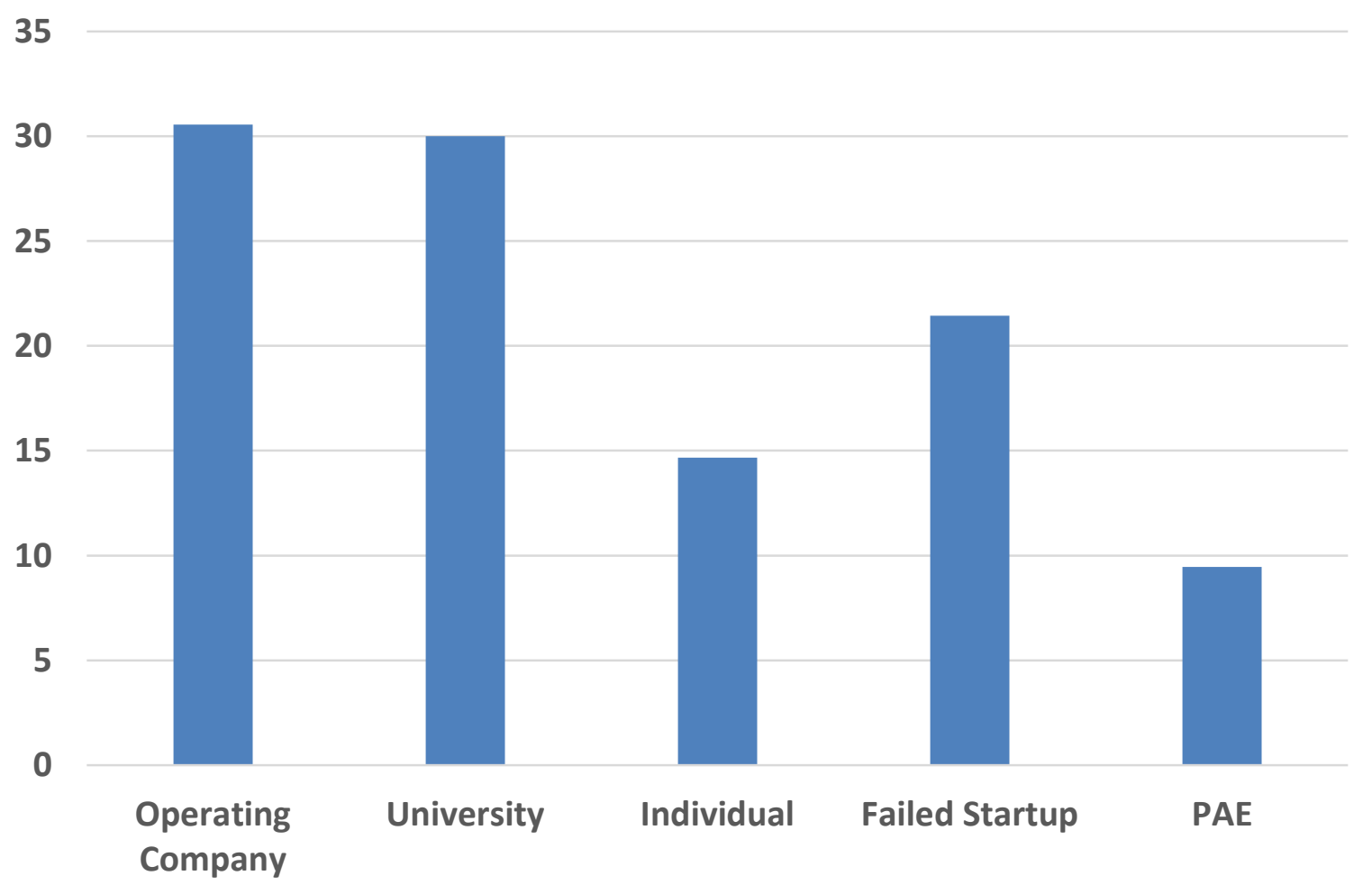

Breaking NPEs down into subtypes reveals considerable variation in the performance of different kinds of NPEs, though no NPE subtype did as well overall as operating companies. Operating companies themselves did not win even a third of their cases which reached a final 
judgment. Universities fared almost as well in court as operating companies, winning $30 \%$ of the time (compared to $30.6 \%$ for operating companies). Failed startups did less well, but better than NPEs as an overall class, winning $21.4 \%$ of the definitive rulings in their cases. Individuals did still less well, winning only $14.7 \%$ of the definitive merits rulings. And PAEs performed least well, winning only $9.5 \%$ of the definitive rulings on patents in their cases. The differences in overall win rate by entity status are highly statistically significant. PAEs also performed significantly worse than operating companies on summary judgment of invalidity (losing $50 \%$ of the time the issue was decided, compared to $26.9 \%$ for operating companies) and on direct infringement (winning only $15.6 \%$ of the time the issue is decided, compared with $42.4 \%$ for operating companies). On inadequate disclosure (failure to comply with either the enablement, separate written description, or best mode requirements), PAEs didn't do as badly, although they still fared worse than operating companies (losing $22.7 \%$ of the time the issue is decided, compared with $16.8 \%$ for operating companies). Individual-owned patents did particularly poorly when their validity was challenged for inadequate disclosure, losing $77.8 \%$ of the time the issue was raised). This difference was statistically significant, although the number of observations was only eight. Interestingly, PAEs, failed startups, and universities all did better at trial than operating companies did, though the difference is not statistically significant when tested in a multiple regression that takes other influences into account.

\section{Litigation Outcomes by Industry}

Finally, we wanted to see how our results were affected by two important industry and technology areas: pharmaceutical industry ANDA cases against companies that make generic 
equivalents of patented drugs, ${ }^{107}$ and software technology patent cases. To do this, we separated each type of case from the others.

There were 87 ANDA cases among the cases in our data set that produced a definitive result. Not one of them was an NPE case. That is not surprising, since ANDA cases are filed when a generic pharmaceutical company wants to produce a product that is bioequivalent to a pharmaceutical product that is already on the market. By definition, then, the plaintiffs in ANDA cases are operating companies. Of the 87 definitive decisions in ANDA cases, 48 , or $55.2 \%$, were patentee wins. ${ }^{108}$ Removing those cases from the data set, the NPE win rate remains unchanged at $14.4 \%$, but the non-ANDA operating company win rate drops somewhat, to $24.6 \%$. We present the results in Tables $7 \mathrm{a}$ and $7 \mathrm{~b}$.

107 For discussion of the Hatch-Waxman Act, which set up a procedure for Abbreviated New Drug Applications (ANDAs) by generic companies who want to make a drug bioequivalent to an existing drug, see, e.g., C. Scott Hemphill \& Mark A. Lemley, Earning Exclusivity: Generic Drug Incentives and the HatchWaxman Act, 77 Antitrust L.J. 947 (2011)

108 This number differs slightly from the $52.1 \%$ pharmaceutical industry win rate we reported in Allison et al., Divided, supra note _ , at _, because a small number of pharmaceutical industry cases were not ANDA cases and so are not included in the count here. 


\section{Table 7a}

Patent Owner Definitive Winner (Excluding ANDA Cases)

Operating Companies vs. NPE

\begin{tabular}{|c|c|c|c|c|}
\hline $\begin{array}{l}\text { Top Row = } \\
\text { Frequency; } \\
\text { Bottom Row = } \\
\text { Percentage } \\
*=\mathrm{p}<0.05 ; * *=\mathrm{p} \\
<0.01 ; * * *=\mathrm{p}< \\
0.001\end{array}$ & $\begin{array}{l}\text { Operating } \\
\text { Company }\end{array}$ & NPE & Total & $\begin{array}{l}\text { Comp. of } \\
\text { proportions } \\
\text { (Fisher's } \\
\text { Exact test) p- } \\
\text { value }\end{array}$ \\
\hline $\begin{array}{lr}\text { Patent } & \text { Owner } \\
\text { Definitive } & \text { Winner } \\
\text { (Excluding } & \text { ANDA } \\
\text { Cases) } & \end{array}$ & 88 & 27 & 115 & \\
\hline & $24.6 \%$ & $14.4 \%$ & & $0.006 * *$ \\
\hline
\end{tabular}

Table 7b

Patent Owner Definitive Winner (Excluding ANDA Cases)

Operating Companies vs. NPE Subtypes

\begin{tabular}{|c|c|c|c|c|c|c|}
\hline $\begin{array}{l}\text { Top Row = } \\
\text { Frequency; } \\
\text { Bottom Row = } \\
\text { Percentage } \\
*=\mathrm{p}<0.05 ; * *=\mathrm{p} \\
<0.01 ; * * *=\mathrm{p}< \\
0.001\end{array}$ & $\begin{array}{l}\text { Operating } \\
\text { Company }\end{array}$ & University & Individual & $\begin{array}{l}\text { Failed } \\
\text { Startup }\end{array}$ & PAE & Total \\
\hline $\begin{array}{l}\text { Patent Owner } \\
\text { Definitive Winner } \\
\text { (Excluding ANDA } \\
\text { Cases) }\end{array}$ & 88 & 3 & 11 & 6 & 7 & 115 \\
\hline & $24.6 \%$ & $30.0 \%$ & $14.7 \%$ & $21.4 \%$ & $9.5 \% * *$ & \\
\hline
\end{tabular}

We also ran the results excluding separating all primary software cases from those that were not software. We present the results in Tables 8 and 9. Table 8 shows that operating companies actually do slightly worse than NPEs in enforcing software patents, winning $12.4 \%$ of the definitive rulings (compared with $14.5 \%$ for NPEs). This is not a statistically significant difference, however. No matter who owns them, software patents as a whole fare worse in cases that do not settle before a final merits ruling than other types of patents, with an average 
win rate in definitive rulings of just $13.6 \%$, compared with at $32.6 \%$ win rate overall for non-

software patents. ${ }^{109}$

Table 8a

Patent Owner Definitive Winner (Only for Primary Software) Operating Companies vs. NPE

\begin{tabular}{|l|l|l|l|l|l|}
\hline $\begin{array}{l}\text { Top Row = Frequency; } \\
\text { Bottom Row = Percentage }\end{array}$ & $\begin{array}{l}\text { Operating } \\
\text { Company }\end{array}$ & NPE & Total & $\begin{array}{l}\text { Comp. of proportions } \\
\text { (Fisher's Exact test) } \\
\text { p-value }\end{array}$ \\
\hline $\begin{array}{l}\text { Patent Owner Definitive } \\
\text { Winner (Only for Primary } \\
\text { Software) }\end{array}$ & 12 & 18 & 30 & & \\
\hline & $12.4 \%$ & $14.5 \%$ & & & 0.696 \\
\hline
\end{tabular}

Table 8b

Patent Owner Definitive Winner (Only for Primary Software) Operating Companies vs. NPE

\begin{tabular}{|c|c|c|c|c|c|c|}
\hline $\begin{array}{l}\text { Top Row = } \\
\text { Frequency; } \\
\text { Bottom Row = } \\
\text { Percentage } \\
*=p<0.05 ; * * \\
=p<0.01 ; * * * \\
=p<0.001\end{array}$ & $\begin{array}{l}\text { Operating } \\
\text { Company }\end{array}$ & University & Individual & $\begin{array}{l}\text { Failed } \\
\text { Startup }\end{array}$ & PAE & Total \\
\hline $\begin{array}{l}\text { Patent Owner } \\
\text { Definitive } \\
\text { Winner (Only } \\
\text { for Primary } \\
\text { Software) }\end{array}$ & 12 & 3 & 4 & 5 & 6 & 30 \\
\hline & $12.4 \%$ & $37.5 \%$ & $26.2 \%$ & $26.3 \%$ & $10.9 \%$ & \\
\hline
\end{tabular}

Notably, however, different NPEs vary widely in their success rate with software patents. Individuals and PAEs fare the worst, winning just $9.5 \%$ and $10.9 \%$ of the time a merits

109 Notably, that lower software patent win rate comes from decisions before the Supreme Court's 2014 ruling in Alice Corp Pty Ltd v CLS Bank International, 134 S Ct 2347 (2014), which led to a spate of invalidations of software patents in the last year because of lack of patentable subject matter. See, e.g., Robert Sachs, A Survey of Patent Invalidations Since Alice, http://www.law360.com/articles/604235/asurvey-of-patent-invalidations-since-alice. So the effective win rate of software patents today is likely quite a bit lower than it was in the period of our study. 
ruling is made, respectively. But failed startups and universities both do substantially better than operating companies at enforcing software patents through judgment.

Once software patents are excluded, patentees overall do better, winning $32.4 \%$ of the non-software cases with a definitive resolution. But operating companies do much better than NPEs; they win $35.6 \%$ of the non-software cases with a merits ruling, compared with only at $14.3 \%$ win rate for NPEs. It should be noted that there were only 9 observations for NPEs. ${ }^{110}$

Table 9a

Patent Owner Definitive Winner (Excluding Primary Software) Operating Companies vs. NPE

\begin{tabular}{|l|l|l|l|l|l|}
\hline $\begin{array}{l}\text { Top Row = Frequency; } \\
\text { Bottom Row } \\
\text { Percentage } \\
*=p<0.05 ; * *=p< \\
0.01 ; * * *=\mathbf{p}<0.001\end{array}$ & $\begin{array}{l}\text { Operating } \\
\text { Company }\end{array}$ & NPE & Total & $\begin{array}{l}\text { Comp. of proportions } \\
\text { (Fisher's Exact test) } \\
\text { p-value }\end{array}$ \\
\hline $\begin{array}{l}\text { Patent Owner Definitive } \\
\text { Winner (Excluding } \\
\text { Primary Software) }\end{array}$ & 124 & 9 & 133 & & \\
\hline & $35.6 \%$ & $14.3 \%$ & 1 & & $0.001^{* * *}$ \\
\hline
\end{tabular}

110 Notably, most NPE cases in our data set were software patents; there were 124 definitive resolutions of NPE software patents but only 63 NPE non-software cases that went to judgment. Remarkably, eight of the ten university patent cases that went to judgment in our data set were software patent cases. But every type of NPE litigated more software than non-software cases in our data set, even though software cases accounted for just over a third of the whole data set. 


\section{Table 9b}

Patent Owner Definitive Winner (Excluding Primary Software) Operating Companies vs. NPE Subtypes

\begin{tabular}{|c|c|c|c|c|c|c|}
\hline $\begin{array}{l}\text { Top Row }=\text { Frequency; } \\
\text { Bottom Row } \\
\text { Percentage } \\
*=p<0.05 ; * *=p< \\
0.01 ; * * *=p<0.001\end{array}$ & $\begin{array}{l}\text { Operating } \\
\text { Company }\end{array}$ & University & Individual & $\begin{array}{l}\text { Failed } \\
\text { Startup }\end{array}$ & PAE & Total \\
\hline $\begin{array}{l}\text { Patent Owner Definitive } \\
\text { Winner (Excluding } \\
\text { Primary Software) }\end{array}$ & 124 & 0 & 7 & 1 & 1 & 133 \\
\hline & $35.6 \%$ & $0.0 \%$ & $21.2 \%$ & $11.1 \%$ & $5.3 \% * *$ & \\
\hline
\end{tabular}

No NPE did particularly well in the fully adjudicated non-software patents. Excluding universities, which took only two non-software cases to judgment in our data set (and lost both), PAEs won a surprisingly small $5.3 \%$ of their non-software cases. Individuals, by contrast, did better in non-software than in software cases, winning $21.2 \%$.

From our data, the definitive win rate for software patents in the computer industry were not noticeably different from the win rate for software patents in other industries. The definitive win rate for software patents in the computers and other electronics industry was $12.3 \%$ ( 8 out of 58 ) and the definitive win rate for software patents outside that industry was $13.8 \%$ (22 out of 163), a difference that is not statistically significant.

\section{Multivariate Regressions}

In our prior papers, we have explored the relationships between various characteristics of the patent, the patent owner, the court, and the patent's technology and industry in influencing the outcome of cases. We have already seen that many of those characteristics 
differentially are correlated with operating company and NPE litigation. For instance, more NPEs file suit in the Eastern District of Texas. ${ }^{111}$ In the cases that reach a merits ruling, the Eastern District of Texas is more likely to rule for patentees than other districts. ${ }^{112}$ The Eastern District of Texas is also more likely to issue merits rulings than the average judicial district. ${ }^{113}$ NPEs are also more likely to enforce software patents. Software patents that reach a final judgment are less likely to prevail. ${ }^{114}$ In this section, we combine our work on entity status with the work in our prior papers to see whether those other factors explain the differences between operating companies and various types of NPEs. Our goal in using a regression is to assess whether the various measures of case success are higher for operating companies than NPEs, while at the same time controlling for a variety of other factors that may compromise the assessment. One risk in doing so is that because we explore so many variables, there may simply not be enough observations to find statistical significance. ${ }^{115}$

We ran various alternative formulations of the logistical regression model. ${ }^{116}$ Because of the high correlation between technology and industry variables, we could not include both technology and industry in the same model. For similar reasons, we could not include both primary technologies and primary + secondary technologies in the same model. The model we

\footnotetext{
111 Cotropia et al, supra note

112 Allison et al., Understanding, supra note _..

113 Allison et al., Understanding, supra note _ at 1779, table 1.

114 Allison et al., Divided, supra note _..

115 Sometimes, because of the numbers of observations, it is not possible to perform regression analysis at all when the number of variables reaches a certain point (a problem with the available "degrees of freedom"), much less to find statistical significance.

116 A full set of the results of alternative specifications is available from the authors upon request.
} 
ultimately focus on includes controls for entity status (both NPEs as a whole and, separately, each NPE subtype), a variety of characteristics of the patent and the lawsuit, the three busiest patent litigation districts, and our various technology categories. We report the results in Tables 10 (for all NPEs) and 11 (for NPEs separated into subtypes) in the Appendix. ${ }^{117}$ We also performed various robustness checks, running additional regression models for the following litigation outcomes: patentee definitive wins; summary judgment of invalidity; summary judgment of non-infringement; summary judgment of non-infringement plus stipulated judgments; and patentee trial wins. For these outcomes, we included in our regression various subsets of the control variables reported in Table 10. In unreported results, we found that the entity status variable results are consistent across the various regression models.

On the overarching question of the likelihood of a patentee win, operating companies won a higher percentage of their cases than did NPEs as a whole, but after we took all other factors into account, the greater likelihood of an operating company win was not significant

${ }^{117}$ A cautionary note about our logistic regression analyses is required: when running multiple tests from the same data set, it is possible to obtain one or more findings of statistical significance by pure chance (the "false discovery rate," or "FDR" problem). It is rare for a researcher in the social sciences to even mention the problem, because available corrective techniques are too punitive by a large factor. These techniques were created for use in studies in which thousands of tests were performed using the same data set. We want to call readers' attention to the issue, however, and caution that there could be a small number of findings of significance in our results that are "false positives," findings of significance that are not real. Thus, one should be hesitant to consider findings of significance at the $\underline{p}<0.10$ level as meaningful. It is also possible that a small number of findings at $\underline{p}$-values below $\underline{p}<0.05$ are not real. Many of our findings of statistical significance are at levels far below 0.05 , and a number that are well below $\underline{p}<0.01$-levels that give us meaningful confidence that what we find is likely to be real. Concerns about false positives are also mitigated by the fact that our general results with respect to entity types are consistent among a series of different regression models. Moreover, as observed earlier, this is a population study and not a sample study. If one focuses only on the differences between entity types in the cases in our particular data set, these differences are significant by definition. However, if one wishes to extrapolate to cases outside our data set, one must deal with the various concerns about statistical significance. 
statistically at the standard $95 \%$ confidence level $(p=0.0532)$, but was at a $90 \%$ confidence level. ${ }^{118}$ Notably, however, once we separated out ANDA cases and NPE cases technology field was no longer a significant explanatory factor in patent owner wins.

Operating companies, then, were not demonstrably more likely than NPEs to win their patent cases when all other potentially explanatory factors were considered, though the evidence does show that operating companies were significantly less likely to lose on summary judgment of both invalidity and noninfringement.

One reason for the weak significance findings in the operating company vs. NPE comparison becomes evident when we break NPEs into their constituent parts. As Table 11 in the Appendix shows, compared with operating companies, individual patent plaintiffs, and PAEs are significantly less likely to win their cases, while universities are significantly more likely than operating companies to win. ${ }^{119}$ Individuals and PAEs are also significantly more likely to lose on summary judgment on both invalidity and noninfringement. The reason NPE results are not statistically significant, in other words, is that NPEs are not a monolithic group.

\section{Implications}

There are important, policy-relevant questions related to how operating companies fare relative to NPEs in patent enforcement. Answering these policy questions may inform the issues currently being considered by Congress, such as heightening the pleading standards in

\footnotetext{
${ }^{118}$ Some of our findings from prior studies retained their statistical significance in this one. Patentees were significantly more likely to lose cases originally brought as declaratory judgments. They were significantly more likely to win cases in the Eastern District of Texas, even after controlling for NPE status, and ANDA plaintiffs were significantly more likely to win.

119 Failed startups are not significantly less likely than operating companies to win their cases.
} 
patent infringement complaints, limiting discovery before claim construction, and staying suits against allegedly infringing manufacturers' customers in certain circumstances. ${ }^{120}$

Our data helps to illuminate the differences between operating company and PAE litigation in cases that reach a final judgment. But it is only part of the picture. First, our dataset lacks any data on patent enforcement that does not result in litigation, such as occurs when demand letters from patent owners to accused infringers result in settlements, typically licenses in return for payment. Second, and more importantly, we lack information about litigated (filed) yet unadjudicated lawsuits. This category, which is comprised largely of voluntary settlements, accounts for approximately $90 \%$ of the patent cases filed in the time frame of our study.

Since we don't observe the cases that settle before a final decision, what can we make of our findings? The cases that reach a merits ruling are not a random sample of all filed cases. If the patent-cases in our dataset are representative of all patent lawsuits, then our data directly shed light on the important policy questions. But even if our dataset is not representative of all filed lawsuits, our findings are still relevant. First, they are directly relevant to debates that focus only on the outcomes of lawsuits as opposed to the litigation process, because we do have data on the cases that make it to final rulings. ${ }^{121}$ Even as to cases that settle, our findings might still be significant. It may be that our findings understate the results

\footnotetext{
120 PATENT Act, H.R. 9 (2015).
}

121 One of the authors, Schwartz, believes that the litigation policy-relevant debates are about how different types of entities participate in the litigation process, not the potentially biased and small subset of cases that reach a final judgment. 
on settled cases, which would mean that our results are even more telling. But it may be that they overstate the results, which would make the implications substantially narrower.

Below we first discuss some potential mechanisms by which filed cases reach (or don't reach) a merits decision and that might skew the results in decided cases. Some of these mechanisms would result in our findings understating our results, while others would mean our findings are overstated. Then we set forth the implications of our study if one makes an assumption that our dataset is representative of all litigated patents.

\section{A. Cautions and Selection Effects}

As we mentioned at the outset, there may be reasons to think the cases we study are not representative of all litigated cases. Some scholars have contended that the cases that are tried rather than settled are the closest cases - that is, the ones characterized by the greatest uncertainty about ultimate outcomes. More specifically, George Priest and Benjamin Klein have suggested that tried cases should have a 50 percent plaintiff win rate. ${ }^{122}$ Our results, including the win-rate data from each of type of entity are inconsistent with the strong Priest-Klein 50 percent hypothesis. Subsequent law-and-economics literature provides a more nuanced set of factors that affect settlement and adjudication of disputes. This more recent literature argues

122 George L. Priest and Benjamin Klein, The Selection of Disputes for Litigation, $13 \mathrm{~J}$ Legal Stud 1, 16-17 (1984). Others have criticized the relevance of the strong Priest-Klein theory to patent litigation. See, for example, Jason Rantanen, Why Priest-Klein Cannot Apply to Individual Issues in Patent Cases *38 (University of lowa Legal Studies Research Paper No 12-15, Aug 2012), archived at http://perma.cc/X994-NSRJ; David L. Schwartz, Pre-Markman Reversal Rates, 43 Loyola LA L Rev 1073, 1101-07 (2010). And Steven Shavell has argued that Priest and Klein are wrong as a general matter of theory. Steven Shavell, Any Frequency of Plaintiff Victory at Trial Is Possible, 25 J. Legal Stud. 493 (1996). 
that deviations from the 50 percent win rate can be caused by a variety of factors, including asymmetric stakes, costs, and risk profiles; information asymmetries; agency costs; endowment effects; and other complicating factors. ${ }^{123}$

These factors, as applied specifically to different entity types in patent litigation, help us hypothesize about the approximately $90 \%$ of filed lawsuits that are not in our dataset. What do those $90 \%$ look like? Do they differ across entity types in the same or opposite ways from our dataset of adjudicated cases? Should they be treated as patentee wins? Others have argued that they should. ${ }^{124}$ But they could just as easily be viewed as accused infringer wins; the point of a settlement is precisely that it is acceptable to both parties. We have no data on settlements, and if there were frequent high dollar amount unobserved settlements that differed substantially by entity type, it likely would affect our analysis.

How we treat settlements depends upon the research question we seek to answer. If we are interested in how many cases have some legal merit, then it makes sense to include nonnuisance-value settlements. If, however, we instead are interested in how many cases would have won on the merits without settlement, then we think counting every settlement as a patentee win does not make any more sense than counting every settlement as a patentee loss.

123 See, for example, Kevin M. Clermont, Litigation Realities Redux, 84 Notre Dame L Rev 1919, 1951-56 (2009) (discussing the difficulties in measuring outcomes because of the prevalence of settlements); Kevin M. Clermont and Theodore Eisenberg, Litigation Realities, 88 Cornell L Rev 119, 137-40 (2002) (discussing the effect of settlement on win rates); Daniel Kessler, Thomas Meites, and Geoffrey Miller, Explaining Deviations from the Fifty-Percent Rule: A Multimodal Approach to the Selection of Cases for Litigation, 25 J Legal Stud 233, 237, 242-48 (1996) (considering "seven characteristics of cases that law-and-economics models predict would affect the plaintiff win rate in litigated cases within the divergent expectations framework").

124 See, e.g., Christopher M. Holman, Do Biotech Patent Lawsuits Really 'Overwhelmingly Lose? A Response to Our Divided Patent System, 34 Biotechnology L. Rep. 59 (2015). 
Parties settle because it is in their mutual interest to do so. The factors that go into that decision include the merits of the case, but also the cost of pursuing it, the uncertainty and delay in getting a result, how much is at stake for each side, and how that result will affect other cases the parties are involved in. Settlements are important for the patent system, for they may drive behavior without regard to the merits of the dispute. Indeed, one type of PAE is interested only in nuisance-value settlement, and for them the merits of the patent should not matter at all. ${ }^{125}$ But the fact that a defendant paid to settle a suit is not necessarily an indication that the suit was completely meritorious, any more than the fact that the plaintiff took a payment to drop the suit is a concession that it would have lost had the case gone to judgment.

We suspect that the type of entity that enforces the patent is related to why and how cases settle, with some differences even within the entity type categories we used. For instance, Lemley's "bottom-feeder trolls" and "lottery ticket trolls" may differentially settlebottom-feeder settling almost everything and lottery-ticket settling almost nothing-and these are both categorized the same in our entity coding. Below we explain in detail several potential reasons why the $90 \%$ of cases were unadjudicated, and set forth how each reason would affect our results. Some of these would result in our data understating differences between entity types, but others would mean that our observations overstate differences. And because of the nature of our study-evaluating only adjudicated disputes-even the regression model does not fix or control for the selection concerns. That said, our crude comparisons of unadjudicated

125 See, e.g., Lemley \& Melamed, supra note 
cases to adjudicated cases (Table 14, below) provides some support for the view that the selection concerns are not massive. ${ }^{126}$

There are several selection mechanisms that would lead to even stronger differences between entity types than we have found. For instance, it may be that PAEs, more than operating companies, settle weaker cases and bring stronger cases to judgment. On this view, the only cases PAEs take to a ruling on summary judgment or later are their strongest cases. Operating companies, in contrast, often have business reasons to take weaker cases farther along. ${ }^{127}$ If this were true, then even the low PAE win rate we reported would overstate the win rate of the unobserved (settled) cases. Thus, the population of PAE litigated cases would be even weaker than the ones litigated to judgment. But defendants in PAE cases likely have the opposite strategy, wanting to settle the cases they are likely to lose and litigating those they are likely to win. It's hard to predict the net effect.

Another reason that our results may be understated is that PAEs, individual inventors, and failed startups may be more likely to reach a merits ruling than operating companies because they sue more defendants on each patent. More defendants means that it is more likely that at least one defendant won't settle. ${ }^{128}$ Back in the 2008 and 2009 time frame of the study, many defendants were often joined together in a single suit. This permitted defendants to enter into joint defense agreements and potentially lower their costs. Thus, more (and

\footnotetext{
${ }^{126}$ It bears noting that, in addition to settlements and adjudications on the merits, there are procedural dispositions. We did not include non-patent procedural dispositions, such as dismissals for lack of personal jurisdiction, in our data.

127 Id. at _.

${ }^{128}$ Risch, Generation of Patent Litigation, supra note _ at __; Allison et al., Patent Quality, supra note - at _.
} 
weaker) NPE patents would reach the merits phase. If this were true, then our results would understate the win rate of NPE patents if the unobserved cases were included.

Consistent with Lemley's "bottom-feeder troll" model, patent assertion entities may bring nuisance value litigation seeking payouts far, far below the cost of defense. Almost all of these nuisance value cases should rationally settle before a merits ruling. Thus, most of them are not in our dataset. And logically those patents should be weaker than most litigated patents, for the simple reason that the plaintiff is unconcerned with the merits in deciding to sue. If bottom-feeder trolls made up a lot of the settled cases, then the remaining patent assertion entity patents and cases that are in our dataset are the larger and stronger cases. If this is true, then our results would again overstate the win rate of PAE patents if the unobserved cases were included. Yet even with the bottom feeder example, the selection may cut in the opposite direction. It may be that when numerous companies are accused of infringement, the ones with the best non-infringement positions maintain their cases until judgment. If this were true, then the litigated-to-judgment cases would be weaker (from the patentee's perspective) than the settled and unobserved cases.

But there are also several selection mechanisms that may cause our results to be overstated. For example, Erik Hovenkamp has argued that PAEs may litigate weak cases to a ruling (or close to a ruling) in order to gain a reputation as an aggressive litigant. ${ }^{129}$ This could also be economically rational for repeat player NPEs. We are skeptical that this practice occurs

\footnotetext{
${ }^{129}$ Erik N. Hovenkamp, Predatory Patent Litigation: How Patent Assertion Entities Use Reputation to Monetize Bad Patents (available at http://papers.ssrn.com/sol3/papers.cfm?abstract_id=2308115).
} 
on a widespread basis, ${ }^{130}$ particularly since, to affect our results, it would have to be true more of NPEs than patent defendants or operating company plaintiffs, both of which might want to establish a similar reputation. ${ }^{131}$ But if many PAEs utilized this strategy (and it outweighed patent defendants who also wanted to establish such a reputation), then our patent assertion entity win rate data would understate the expected win rate of the unobserved cases.

Second, NPEs may be more likely to litigate using a "war chest" strategy. ${ }^{132}$ The war chest strategy involves asserting the patent against numerous parties, settling with weaker parties to finance the ongoing litigation, and then litigating more aggressively and longer against parties with deeper pockets. The aggressive litigation against the final defendants is partially because all of the other value of the patent has been obtained so there is a smaller downside to having the patent deemed invalid. There is also a smaller downside to taking more aggressive positions on infringement. If this strategy was commonly used by NPEs, then the adjudicated disputes could conceivably be weaker than the average litigation, which would mean that our results overstate the differences between the entities. But even that would not necessarily follow. NPEs on this hypothesis are asserting the same patent against multiple

130 Indeed, two of the authors have previously hypothesized the opposite - that repeat-player NPEs would be more risk averse, since losing even once on a patent can prevent them from asserting the patent against anyone else. Allison et al., Quality and Settlement, supra note

131 While we know of no empirical or even anecdotal evidence of NPEs playing hardball to establish a litigation reputation, we do know that some defendants do so. See, e.g., http://blog.newegg.com/patent-trolls-learn-mess-newegg/. And if defendants are litigating everything, even their weak cases, in order to establish a reputation, our results should overstate, not understate, the quality of all NPE patents. There is an argument that defendants generally do not litigate weak cases to judgment because of risk-aversion via agency costs. NPEs generally are not faced with these agency costs.

132 David L. Schwartz, The Rise of Contingent Fee Representation in Patent Litigation, 64 Ala. L. Rev. 335, 344, 368-69 (2012). 
entities, so the validity of that patent should not significantly vary. ${ }^{133}$ At most it should affect infringement results. And even then the rational war chest strategy may turn more on what the defendant has at stake rather than how strong the infringement case is. So it is not necessarily true that the later case that goes to judgment is harder to win than the cases before it that settled, although PAEs may prefer to "swing for the fences" after receiving settlements from all of the other accused infringers. And war chest PAEs may rationally pursue weaker claims of infringement against the final defendants with the highest exposure.

Individual inventors and failed startups may also behave differently than other litigants. As the original inventors of the patents, they may be subject to certain endowment effects, believing that their invention is better than it is. ${ }^{134}$ Moreover, individual inventors may be irrational with respect to settlement and have fewer people to whom they owe a fiduciary duty of care. ${ }^{135}$ Table 3 provides limited evidence that individual inventors settle at different rates than other entity types. There is some experimental data suggesting that individual inventors sell to patent speculators because of the high cost of litigation, which is rational but also means that the categories we used are somewhat fluid. ${ }^{136}$ Finally, failed startups may be willing to litigate until judgment rather than settle because the entity as a commercializing business has failed. There is nothing to focus on other than enforcement of the patent. Notably, these

\footnotetext{
${ }^{133}$ In practice, settlements in prior cases may serve as some evidence that the patent is non-obvious. Id. at 368-39.

134 Experimental evidence has suggested the existence of an endowment effect among inventors. See, e.g., Christopher Buccafusco \& Christopher Jon Sprigman, The Creativity Effect, 78 U. Chi. L. Rev. 31 (2011).

135 David L. Schwartz, On Mass Patent Aggregators, 114 Colum. L. Rev. Sidebar 51, 59 (2014).

136 Stephen Haber \& Seth H. Werfel, Why Do Inventors Sell to Patent Trolls? Experimental Evidence for the Asymmetry Hypothesis, available at http://papers.ssrn.com/sol3/papers.cfm?abstract_id=2552734.
} 
possible selection effects could explain some, but not all, of our results. In particular, they should not have an effect on our PAE results.

Other selection mechanisms are complicated and ambiguous as to how they would impact our results. Most NPEs have fewer reputational concerns than operating companies have. ${ }^{137}$ One might expect NPEs unconstrained by these concerns to assert weaker patents. But pointing in the other direction is the fact that NPEs' primary assets are patents. It would be extremely bad for business if their patents were adjudicated invalid or not infringed. Their entire revenue stream for that patent could disappear, and they lack a commercial product to profit from. For this reason, some have speculated that NPEs may be more risk averse than similarly situated practicing entities. ${ }^{138}$

PAEs, individuals, and failed startups all have fewer chances to settle cases than operating companies because they can't settle via a cross license or other business deal. On the other hand, NPEs are unlikely to be entitled to injunctive relief if they prevail. ${ }^{139}$ Both of these affect settlement. Because NPEs are only interested in a monetary payment, they may be more likely to settle cases than companies whose incentives are asymmetric. The evidence that exists is mixed on differences between NPE and non-NPE settlement rates. ${ }^{140}$ Thus, a marginal NPE

\footnotetext{
137 Lemley \& Melamed, supra note _, at _ (making this point).

138 Allison et al., Quality and Settlement, supra note _.

139 See, e.g., Colleen V. Chien \& Mark A. Lemley, Patent Holdup, the ITC, and the Public Interest, 98
} Cornell L. Rev. 1, tbl. 1 (2012). There is some evidence that litigants can predict the cases that courts will deny requests for injunctions, and therefore voluntarily choose not to pursue the equitable remedy. See Kirti Gupta \& Jay P. Kesan, Studying the Impact of eBay on Injunctive Relief in Patent Cases (available at http://papers.ssrn.com/sol3/papers.cfm?abstract_id=2629399).

140 Compare Allison, Lemley, and Walker, 99 Georgetown L J at 694 (finding that, of the most litigated patents, the NPE settlement rate was not statistically different from the non-NPE settlement 
case may reach judgment while a marginal operating company case may not, or vice versa. It is hard to assess which way this would cut if it were true. It depends whether the additionally settled cases are stronger or weaker than average.

The nature of plaintiff's lawyers may also matter. Settlement dynamics are strongly related to whether the plaintiff is represented on an hourly-basis, contingent fee basis, or on the basis of some hybrid arrangement. It is likely that most operating company litigation is on an hourly attorney fee basis and much NPE work is done on a contingent fee basis. ${ }^{141}$ We believe that substantially all of the legal work done on behalf of defendants is on an hourlybasis or modified hourly basis. There is not yet a robust insurance market for patent infringement claims, so most companies bear their own legal defense costs. Contingent-fee representation may affect the types of cases that go to judgment, especially when the defense work is done on an hourly basis. ${ }^{142}$ Again, however, it is hard to tell what that effect would be. ${ }^{143}$ In theory, contingent-fee lawyers may be more likely to seek early settlement, which rate), with Michael Risch, A Generation of Patent Litigation: Outcomes and Patent Quality, 52 San Diego L Rev 2 (2015), (finding that the most litigious NPEs have a higher settlement rate than a matched set of once-litigated patents). Notably, both of these studies oversampled repeat litigants (the focus of those studies) and therefore are not strictly representative of the population as a whole. However, they provide some information on what happened when the same patent was litigated multiple times.

${ }^{141}$ David L. Schwartz, The Rise of Contingent Fee Representation in Patent Litigation, 64 Ala. L. Rev. 335, 344, 371-77 (2012).

${ }^{142}$ Contingent fee representation reduces the plaintiff's upfront transaction costs (fees and often expenses) relative to the amount in dispute and relative to the upfront expense the defendant must incur. Settlement strategy is based on a combination of the perceived merits of the case (validity and infringement), damages, and the cost of defense.

${ }^{143}$ We might expect plaintiffs represented by contingent-fee lawyers to bring more (and weaker) cases than other plaintiffs. Or, because the contingent-fee lawyers screen cases before accepting to handle them on a contingent basis, the lawsuits they bring may be stronger than other plaintiffs' lawsuits - or at least more likely to result in a payment in settlement, which is not necessarily the same thing. Plaintiffs represented on a contingency-fee basis may be more likely to settle those cases. 
generates revenue for them with a minimum amount of work, while in theory hourly billing lawyers may be more willing to continue to litigate regardless of the merits or benefits to the client, as that approach generates extra revenue for the lawyers. And the asymmetry between plaintiffs' and defendants' early-stage litigation costs may encourage the bottom-feeder litigation model. These factors certainly have an effect on which cases are selected for final judgment.

For each of these selection concerns, it is difficult to answer the policy-relevant questions about NPEs. Our results may be understated, in which case NPEs perform much worse in litigation than operating companies. If NPEs perform much worse in litigation, Congress should take note. Alternatively, our results may be overstated compared to the whole population of litigated cases. While we have personal prior beliefs about the plausibility of these potential selection mechanisms, empirical data on them is largely lacking. We believe that further investigation into the truth or falsity, as well as frequency and magnitude, of each of these mechanisms is warranted.

In a first effort at assessing the magnitude and direction of possible selection effects, we compared the technologies, industries, and entity types present in our data set with those for a small random sample of "unadjudicated" patents involved in lawsuits filed in 2008 and 2009, that is, patents in lawsuits that were filed during the same two-year period as those cases in our data set but that did not reach a merits decision. ${ }^{144}$ Tables 12,13 , and 14 below compare on the basis of technology, industry, and entity type, respectively.

144 We randomly sampled lawsuits filed in 2008 and 2009 (separately). We stratified the lawsuits to separate seven busy judicial districts (C.D. Cal., S.D.N.Y., N.D. Cal., N.D. III., E.D. Tex., D. Del., D.N.J.) and 
The columns in these tables require some interpretation before being compared with each other. The second and third columns from the left provide the percentage of asserted utility patents, both in our merits data set and in the random sample of filed cases. The two columns on the far right collapse the patent-level information into a case-level observation. While the patent-case and case bases differ, a comparison is useful to see basic trends.

First, as we reported in a previous paper, ${ }^{145}$ fewer than $10 \%$ of the patent lawsuits filed in 2008 and 2009 (462 of 5,029) resulted in any merits decision. In other words, more than $90 \%$ of lawsuits settled or were disposed of on nonsubstantive grounds before the court resolved summary judgment or tried the case.

an omnibus "other" category. We randomly sampled from within these eight strata for each year. The busy judicial districts accounted for approximately $50 \%$ of filings in both years. $(48.2 \%$ in 2008 , and $51.1 \%$ in 2009). We dropped design patents, as well as patents that were already in our dataset of adjudicated patents. Allison coded the technology and industry of the 210 patents that were at issue in the random draw of lawsuits. Schwartz coded the entity status of these patents. We recognize that this is a relatively small random sample, but we believe it is important to attempt to evaluate potential selection concerns.

145 Allison et al., Understanding Realities, supra note at 
Table 12

2008-2009 Filings v. Adjudications by Technology ${ }^{146}$

\begin{tabular}{|l|l|l|l|l|}
\hline Technology & $\begin{array}{l}\% \quad \text { Adjudicated } \\
\text { Patents }\end{array}$ & $\begin{array}{l}\text { \% Filed But } \\
\text { Unadjudicated } \\
\text { Patents }\end{array}$ & $\begin{array}{l}\text { \% Adjudicated But } \\
\text { Lawsuits }\end{array}$ & $\begin{array}{l}\text { Filed } \\
\text { Unadjudicated } \\
\text { Lawsuits }\end{array}$ \\
\hline Mechanical & $28.7 \%(271)$ & $29.0 \%(61)$ & $29.6 \%(137)$ & $33.8 \%(34.5)$ \\
\hline Electrical & $11.0 \%(104)$ & $11.0 \%(23)$ & $10.3 \%(48)$ & $9.4 \%(9.5)$ \\
\hline Chemistry & $16.3 \%(154)$ & $20.0 \%(42)$ & $16.4 \%(76)$ & $22.5 \%(23)$ \\
\hline Biotech & $5.3 \%(50)$ & $4.3 \%(9)$ & $4.2 \%(19)$ & $2.9 \%(3)$ \\
\hline Software & $34.8 \%(329)$ & $32.4 \%(68)$ & $34.8 \%(162)$ & $25.4 \%(25.9)$ \\
\hline Optics & $3.9 \%(37)$ & $2.9 \%(6)$ & $4.8 \%(22)$ & $4.9 \%(5)$ \\
\hline
\end{tabular}

We used Fisher's Exact test to compare the distribution of proportions among technology areas for Adjudicated Patents with the same distribution for Filed-ButUnadjudicated Patents. The difference in the two distributions was not statistically significant; indeed, the distributions were almost identical $(p=0.986) .{ }^{148}$

146 In Tables 12, 13, and 14, we report percentages with the number of observations in parenthesis in each cell.

147 For purposes of Tables 12, 13, and 14, we collapsed our dataset using patent-lawsuit as the unit of observation to a dataset using the lawsuit as the unit of observation. In some lawsuits, the asserted patents were in different industries and/or technologies. When we collapsed the dataset, we weighted the industries and/or technologies in these split lawsuits. For instance, if a lawsuit involved two patents, one in the mechanical technology and the other in the chemistry technology, we classified the lawsuit as $50 \%$ mechanical and $50 \%$ chemistry. Because of rounding, the sums do not always equal exactly $100 \%$.

${ }^{148}$ To be sure, if the selection largely occurs within technology, industry, or entity type, then Tables 13 and 14 does little to exclude that selection is driving our results. Ideally, we would like some measure that the adjudicated patents are of similar quality to the unadjudicated patents. We lack such a measure for our data. 
Table 13

2008-2009 Filings v. Adjudications by Industry

\begin{tabular}{|l|l|l|l|l|}
\hline Industry & $\begin{array}{l}\% \\
\text { Adjudicated } \\
\text { Patents }\end{array}$ & $\begin{array}{l}\% \text { Filed But } \\
\text { Unadjudicated } \\
\text { Patents }\end{array}$ & $\begin{array}{l}\text { \% Adjudicated } \\
\text { Lawsuits }\end{array}$ & $\begin{array}{l}\text { Filed But } \\
\text { Unadjudicated } \\
\text { Lawsuits }\end{array}$ \\
\hline $\begin{array}{l}\text { Computer \& Other } \\
\text { Electronics }\end{array}$ & $13.7 \%(129)$ & $17.1 \%(36)$ & $\begin{array}{l}14.8 \% \\
(68.7)\end{array}$ & $12.7 \%(12.9)$ \\
\hline Semiconductor & $3.1 \%(29)$ & $9.0 \%(19)$ & $1.8 \%(8.3)$ & $4.7 \%(4.8)$ \\
\hline Pharmaceuticals & $11.6 \%(110)$ & $10.5 \%(22)$ & $12.1 \%(56)$ & $12.7 \%(13)$ \\
\hline Medical Devices & $10.5 \%(99)$ & $4.3 \%(9)$ & $9.6 \%(44.3)$ & $8.1 \%(8.3)$ \\
\hline Biotech & $3.2 \%(30)$ & $2.4 \%(5)$ & $2.3 \%(107)$ & $1.0 \%(1)$ \\
\hline Communications & $13.0 \%(123)$ & $8.6 \%(18)$ & $10.3 \%(48)$ & $7.9 \%(8.1)$ \\
\hline Transportation & $4.6 \%(43)$ & $5.2 \%(11)$ & $5.5 \%(253)$ & $5.1 \%(5.3)$ \\
\hline Construction & $3.4 \%(32)$ & $3.3 \%(7)$ & $3.9 \%(18)$ & $5.0 \%(5.1)$ \\
\hline Energy & $2.2 \%(21)$ & $5.7 \%(12)$ & $1.1 \%(15)$ & $5.1 \%(5.2)$ \\
\hline Consumer Products & $14.2 \%(134)$ & $12.4 \%(26)$ & $18.1 \%(83.9)$ & $13.2 \%(13.5)$ \\
\hline Industry Goods & $20.6 \%(195)$ & $20.5 \%(43)$ & $20.6 \%(95.8)$ & $23.2 \%(23.7)$ \\
\hline
\end{tabular}

Fisher's Exact test again showed no statistically significant difference between the distribution of proportions among industry categories for adjudicated patents and the same distribution for filed-but-unadjudicated patents.

Table 14

2008-2009 Filings v. Adjudications by Entity Type

\begin{tabular}{|l|l|l|l|l|}
\hline & $\begin{array}{l}\% \\
\text { Adjudicated } \\
\text { Patents }\end{array}$ & $\begin{array}{l}\text { \% Filed But } \\
\text { Unadjudicated } \\
\text { Patents }\end{array}$ & $\begin{array}{l}\text { \% } \\
\text { Adjudicated } \\
\text { Lawsuits }\end{array}$ & $\begin{array}{l}\text { Filed But } \\
\text { Unadjudicated } \\
\text { Lawsuits }\end{array}$ \\
\hline Patent Holding Company & $11.0 \%(104)$ & $11.4 \%(24)$ & $12.3 \%(57)$ & $12.7 \%(13)$ \\
\hline Individual Inventor & $11.7 \%(111)$ & $8.1 \%(17)$ & $14.9 \%(69)$ & $10.3 \%(10.5)$ \\
\hline Operating Company & $72.1 \%(681)$ & $73.8 \%(155)$ & $66.8 \%(310)$ & $72.1 \%(73.5)$ \\
\hline PAE (broad definition) & $27.9 \%(264)$ & $25.7 \%(54)$ & $33.2 \%(154)$ & $27.0 \%(27.5)$ \\
\hline
\end{tabular}


Again, Fisher's Exact test revealed no statistical significance between the distribution of proportions among entity types for adjudicated patents and the distribution of proportions among entity types for filed-but-unadjudicated patents.

As shown in Table 12, we note some relative balance between adjudicated and filed patents and lawsuits based on technology with a few notable exceptions. This may give us some comfort that selection effects are not the primary driving force in our results. Software lawsuits appear to be far overrepresented $(34.8 \%$ of the lawsuits in our dataset compared to $25.9 \%$ of filed cases), suggesting that a greater percentage of software cases go to judgment than other types of cases. On the other hand, the difference in the number of software patents asserted and adjudicated is far less pronounced, and we are not sure why. Both chemistry patents and lawsuits are somewhat underrepresented in our data set, suggesting that chemistry patents are less likely than others to go to judgment. With respect to industry, as shown in Table 13, medical device patents were substantially more likely to be in our adjudicated data set than the unadjudicated sample, although most of the differences disappear when analyzing the data on a case-level. The communications industry was also more likely to be in our data set, both in term of patents and lawsuits, likely because so many of the patents litigated in the communications industry cover software technology. Semiconductor patents were less likely to appear in our data set than in the sample of filed-but-unadjudicated cases.

With respect to entity type, as shown in Table 14, patent holding companies appear to be relatively balanced in terms of patents and lawsuits. Individual inventors are 
overrepresented in our dataset relative to the filed cases. ${ }^{149}$ NPEs, using a broad definition, are overrepresented on a lawsuit basis, but only slightly on a per-patent basis. We do not have a clear explanation for the differences between the per-patent basis and the per-lawsuit basis. As with industry and technology, we are somewhat comforted by the absence of dramatic selection differences between the two data sets, which may help to ameliorate some of the concerns discussed in this section. However, even comparing filed-but-unadjudicated cases by industry, technology, and entity type with the adjudicated cases in our data set cannot capture selection that affects who decides to file a lawsuit in the first place. It is, of course, still possible that we are observing similar percentages while other unobservable metrics relating to case quality vary.

\section{B. Implications for Patent Reform and Patent Debates}

In this section, we put aside the concerns that we just discussed --- that operating companies and NPEs differentially settle cases in a way that might skew our results based upon decided cases. We make the simplifying assumption that our dataset is sufficiently representative of all patent disputes, even those that settle. With this assumption, we now discuss the implications that flow from our results.

In terms of merits rulings, we find that operating companies fare better than PAEs and individual inventors. Interestingly, in merits rulings, PAEs do most poorly when they are not asserting software patents, winning only $5.3 \%$ of their non-software cases that reach judgment.

149 Our random sample of unadjudicated cases only contained two university patent holders. Given the extremely small number, we don't calculate values for universities. 
We cannot explain why PAEs lose so often. It might be that they assert weaker patents, but it could also be that judges are biased against them for policy reasons, ${ }^{150}$ that their attorneys are less skillful, or that the NPE cases that reach adjudication are worse for some other reason (such as those described in Section IV.A) than the cases that NPEs settle.

We also find that some, but not all, of operating companies' relative success derives from ANDA pharmaceutical cases, where patentees succeed much more often than they do in any other field. Software patents, by contrast, have a lower success rate. The relationship between entity status, software, and the other variables in our study is a complicated one. And while all types of NPE disproportionately asserted software patents, they didn't do measurably worse in software cases than operating companies did. Rather, the win rate was low across the board for software patents.

If our results are representative of all patent litigation, we believe that they have useful implications for continuing policy debates about the patent system generally and patent reform particularly. With this assumption, we offer three implications below.

First, our data suggest that NPEs are far from monolithic. Some of the authors have previously argued that we should be less focused on trying to identify patent "trolls."151 Even for those who do wish to focus attention on them as the source of a problem, it is clear that treating all NPEs alike is a mistake. It makes a big difference in merits decisions in litigation

150 At least one contingent fee attorney believes that judges are biased against NPEs. Schwartz, supra note _ at 378 n.205 (recounting that one contingent fee lawyer stated that "Some judges have great antipathy toward patent speculators.").

151 Lemley \& Melamed, supra note _; Mark A. Lemley, Are Universities Patent Trolls?, 18 Fordham Intell. Prop., Med., \& Ent. L.J. 611 (2008); Schwartz \& Kesan, Analyzing the Role of Non-Practicing Entities in the Patent System, 99 Cornell L. Rev. 425 (2013). 
whether the party in question is a PAE, an individual, a failed start-up, or a university. And while we cannot prove that the difference extends beyond litigation outcomes, it probably makes sense to start talking about the different types of NPEs such as universities, individual inventors, and failed startups differently than PAEs whose business model is to merely acquire patents for the purpose of assertion. This is not to deny that even the narrower category of PAEs isn't worthy of debate for its role in the patent system. PAEs and individual plaintiffs adjudicated by far the most suits of any NPE classes, and they did the least well. But everyone in this debate should be more precise than we often are when talking about patent litigants.

Second, our data help to emphasize the significant differences across technologies and industries in how they experience the patent litigation system. ${ }^{152}$ Pharmaceutical patents in ANDA litigation fare far better in final judgments than patents in any other industry or type of litigation - and not one of them was brought by an NPE of any type. Software patents do worse than those in most other technology fields, ${ }^{153}$ and unlike operating companies, a majority of the suits litigated to judgment by every type of NPE involved software patents. While the outcome data don't suggest that NPE software patents performed more poorly in litigation than did operating company software patents, they nonetheless tell a story of two very different poles in the patent litigation system. Outcomes in ANDA pharmaceutical patent cases and software patent cases look virtually nothing alike, from who wins to where they are adjudicated to the kind of entity that brings the lawsuits. ANDA cases also differ procedurally, with an automatic

152 For discussion of this issue, see, e.g., Dan L. Burk \& Mark A. Lemley, The Patent Crisis and How the Courts Can Solve It (2009).

153 Allison et al., Divided, supra note , at _. 
"30-month stay" which is equivalent to a preliminary injunction. Most ANDA cases are heard by a judge instead of a jury, and the courts hearing bench trials often do not permit summary judgment motions. ${ }^{154}$

Finally, our data highlight the extent to which patent litigation in the United States has separated not only along entity, technology, and industry lines, but also along geographic ones, as well. NPEs other than universities overwhelmingly flock to the Eastern District of Texas, and for good reason: even considering the lower win rate of PAEs and individuals, plaintiffs that take their cases to decision do much better in that district than anywhere else. ${ }^{155}$ By contrast, operating companies file suit in a variety of jurisdictions, and their favorite - the District of Delaware - is no more likely to rule for patentees than average in cases that reach judgment. We have a specialized patent trial court in the United States. It is located in Marshall, Texas, and it specializes not just in patent trials but also is receptive to NPE patent litigation. A large portion of NPE patent litigation outcomes at the ground level were made in the Eastern District of Texas. Reasonable people can differ on whether that is good or bad for the world, ${ }^{156}$ but it is certainly something to keep in mind as Congress considers patent reform directed at NPEs.

\footnotetext{
${ }^{154}$ Allison et al., Our Divided Patent System, supra note ___ at __.

155 Fabio E. Marino \& Teri H.P. Nguyen, Has Delaware Became the "New" Eastern District of Texas? The Unforeseen Consequences of the AIA, 30 Santa Clara High Tech. L.J. 527, 539-40 (2014) ("Recent survey data on new patent suit filings suggests that [NPEs] have found a new 'forum of choice in the District of Delaware.").

156 See, e.g., Daniel M. Klerman \& Gregg Reilly, Forum Selling, _ S. Cal. L. Rev. _ (forthcoming 2016), available at http://papers.ssrn.com/sol3/papers.cfm?abstract id=2538857; Rochelle Cooper Dreyfuss, The Federal Circuit As an Institution: What Ought We to Expect?, 47 Loy. L.A. L. Rev. 827 (2010); Jeff Becker, On Creating Specialized Patent District Courts, 61 SMU L. Rev. 1607 (2008); Jeanne Fromer, Patentography, 85 N.Y.U. L. Rev. 1444 (2010); Paul R. Gugliuzza, Patent Law Federalism, 2014 Wis. L. Rev. 11; Arti K. Rai, Specialized Trial Courts: Concentrating Expertise on Fact, 17 Berkeley Tech. L.J. 877 (2002).
} 
Our results may also have implications for specific legislative proposals. For example, Congress is considering expanding fee shifting to prevailing parties. ${ }^{157}$ The primary justification for enhanced fee shifting is that accused infringers feel economic pressure to settle weak lawsuits because the settlement demands are substantially below the cost of defense. Fee shifting would encourage these defendants to press with litigation instead of settling, which (in theory) would discourage patent holders from bringing weak cases. To evaluate the effects of fee shifting based on this rationale, one would need to include the unadjudicated cases that we lack.

Our results may be more useful to understand what would happen if we shifted fees in cases without warning and without an opportunity for the parties to settle based upon the change. As we have previously written, ${ }^{158}$ the win rate may be driven, in part, by general civil litigation dynamics: defendants have several opportunities for a final judgment in their favor. Defendants can win on summary judgment or trial or appeal, while a patentee must run the table to prevail. But whatever the reason, some may believe that fee shifting in these cases is desirable, and we believe that fee shifting would alter which cases are litigated and settled.

If we shifted fees in all the 2008 and 2009 merits decisions, then NPEs would be responsible for fees in $85 \%$ of the definitive rulings, and patent owners across the board would be responsible for fees in about $75 \%$ of the non-ANDA cases. But no proposal in Congress would go that far. Even if it were not applied to every case, an even-handed fee-shifting rule would probably tend to shift fees to defendants significantly more often than to patent owners, and to

157 PATENT Act, H.R. 9 (2015).

158 Allison et al, Understanding Realities, supra note at 1789; Lemley, Fractioning, supra note _. 
cause PAEs to pay fees more often than operating companies (assuming that the selection concerns aren't driving our results). That is true not only because defendants win most adjudicated cases, particularly against PAEs, but because defendants are much more likely to win pre-trial while patentees more often win at trial, and courts are likely to be reluctant to shift fees in a close case in which neither side could prevail on summary judgment. Of course, the policy debate surrounding fee shifting is complex, as it increases the potential exposure of both plaintiffs and defendants, and another effect of fee shifting is to further advantage larger and financially powerful parties over smaller ones.

\section{Conclusion}

The debate over patent trolls has occupied policy makers in the patent system for the last several years. In this paper, we offer a comprehensive look at one important piece of evidence in that debate - how different types of patent plaintiffs fare in court. We find significant differences by technology, industry, court, and entity type in whether and how patentees win their cases. While our data doesn't resolve the policy debates, it brings realworld evidence to bear on a discussion that is too often based on supposition. 


\section{Appendix}

Table A1

Entire Population of 2008-2009 Adjudicated Patents -Operating Co. vs. NPE Subtypes

\begin{tabular}{|l|l|l|}
\hline & Frequency & Percent \\
\hline $\begin{array}{l}\text { Operating } \\
\text { Company }\end{array}$ & 681 & 72.1 \\
\hline University & 13 & 1.4 \\
\hline Individual & 111 & 11.8 \\
\hline Failed Startup & 36 & 3.8 \\
\hline PAE & 104 & 11.0 \\
\hline Total & 945 & 100.0 \\
\hline
\end{tabular}

Table A2

Proportions Among Districts by Entity Type Compared with Overall District Proportions Operating Companies vs. Broad_NPE

\begin{tabular}{|c|c|c|c|c|}
\hline $\begin{array}{l}\text { Top Row }= \\
\text { Frequency; } \\
\text { Bottom Row = } \\
\text { Percentage } \\
*=p<0.05 ; * *= \\
p<0.01 ; * * * p< \\
0.001\end{array}$ & $\begin{array}{l}\text { Operating } \\
\text { Company }\end{array}$ & Broad_NPE & Total & $\begin{array}{l}\text { Comp. of } \\
\text { proportions } \\
\text { (Fisher's Exact } \\
\text { test) p-value }\end{array}$ \\
\hline \multirow[t]{2}{*}{ TX ED } & 56 & 71 & 127 & \\
\hline & $8.2 \%$ & $26.9 \%$ & & $<0.001^{* * *}$ \\
\hline \multirow[t]{2}{*}{ D ED } & 101 & 21 & 122 & \\
\hline & $14.8 \%$ & $8.0 \%$ & & $0.005 * *$ \\
\hline \multirow[t]{2}{*}{ CA ND } & 64 & 17 & 81 & \\
\hline & $9.4 \%$ & $6.4 \%$ & & 0.156 \\
\hline \multirow[t]{2}{*}{ CA CD } & 32 & 24 & 56 & \\
\hline & $4.7 \%$ & $9.1 \%$ & 1 & $0.014^{*}$ \\
\hline \multirow[t]{2}{*}{ CA SD } & 38 & 13 & 51 & \\
\hline & $5.6 \%$ & $4.9 \%$ & & 0.751 \\
\hline \multirow[t]{2}{*}{ NY SD } & 42 & 5 & 47 & \\
\hline & $6.2 \%$ & $1.9 \%$ & & $0.007 * * *$ \\
\hline \multirow[t]{2}{*}{ IL ND } & 17 & 23 & 40 & \\
\hline & $2.3 \%$ & $8.7 \%$ & & $<0.001^{* * *}$ \\
\hline WI WD & 25 & 3 & 28 & \\
\hline
\end{tabular}




\begin{tabular}{|l|l|l|l|l|} 
& $3.7 \%$ & $1.1 \%$ & & 0.052 \\
\hline NJ D & 29 & 5 & 34 & \\
\hline & $4.3 \%$ & $1.9 \%$ & & 0.117 \\
\hline MA D & 24 & 3 & 27 & \\
\hline & $3.5 \%$ & $1.1 \%$ & & 0.051 \\
\hline VA ED & 24 & 6 & 30 & \\
\hline & $3.5 \%$ & $2.3 \%$ & & 0.411 \\
\hline OH ND & 10 & 7 & 17 & \\
\hline & $1.5 \%$ & $2.7 \%$ & & 0.273 \\
\hline TX SD & 20 & 2 & 22 & \\
\hline & $2.9 \%$ & $0.8 \%$ & & 0.053 \\
\hline All Other Dist. & 199 & 64 & 263 & \\
\hline & $29.2 \%$ & $24.2 \%$ & & 0.145 \\
\hline
\end{tabular}

Table A3

Proportions Among Districts by Entity Type Compared with Overall District Proportions Operating Companies vs. NPE Subtypes

\begin{tabular}{|c|c|c|c|c|c|c|}
\hline $\begin{array}{l}\text { Top Row = Frequency; } \\
\text { Bottom Row } \\
\text { Percentage } \\
*=\mathrm{p}<0.05 ; * *=\mathrm{p}< \\
0.01 ; * * *=\mathrm{p}<0.001\end{array}$ & $\begin{array}{l}\text { Operating } \\
\text { Company }\end{array}$ & University & Individual & $\begin{array}{l}\text { Failed } \\
\text { Startup } \\
\end{array}$ & PAE & Total \\
\hline \multirow[t]{2}{*}{ TX ED } & 56 & 1 & 29 & 14 & 27 & 127 \\
\hline & $8.2 \%$ & $7.7 \%$ & $26.1 \% * *$ & $38.9 \% * *$ & $26.0 \% * *$ & \\
\hline \multirow[t]{2}{*}{ D ED } & 101 & 0 & 2 & 5 & 14 & 122 \\
\hline & $14.8 \%$ & $0.0 \%$ & $1.8 \% * *$ & $13.9 \%$ & $13.5 \%$ & \\
\hline \multirow[t]{2}{*}{ CA ND } & 64 & 1 & 3 & 1 & 12 & 81 \\
\hline & $9.4 \%$ & $7.7 \%$ & $2.7 \% *$ & $2.8 \%$ & $11.5 \%$ & \\
\hline \multirow[t]{2}{*}{ CA CD } & 32 & 0 & 11 & 2 & 11 & 56 \\
\hline & $4.7 \%$ & $0.0 \%$ & $9.9 \% *$ & $5.6 \%$ & $10.6 \% *$ & \\
\hline \multirow[t]{2}{*}{ CA SD } & 38 & 0 & 9 & 2 & 2 & 51 \\
\hline & $5.6 \%$ & $0.0 \%$ & $8.1 \%$ & $5.6 \%$ & $1.9 \%$ & \\
\hline \multirow[t]{2}{*}{ NY SD } & 42 & 0 & 3 & 2 & 0 & 47 \\
\hline & $6.2 \%$ & $0.0 \%$ & $2.7 \%$ & $5.6 \% * *$ & $0.0 \% * *$ & \\
\hline \multirow[t]{2}{*}{ IL ND } & 17 & 0 & 12 & 0 & 11 & 40 \\
\hline & $2.5 \%$ & $0.0 \%$ & $10.8 \% * *$ & $0.0 \%$ & $10.6 \% * *$ & \\
\hline WI WD & 25 & 1 & 0 & 0 & 2 & 28 \\
\hline
\end{tabular}




\begin{tabular}{|l|l|l|l|l|l|l|} 
& $3.7 \%$ & $7.7 \%$ & $0.0 \% *^{*}$ & $0.0 \%$ & $1.9 \%$ & \\
\hline NJ D & 29 & 0 & 5 & 0 & 0 & 34 \\
\hline & $4.3 \%$ & $0.0 \%$ & $4.5 \%$ & $0.0 \%$ & $0.0 \% *$ & \\
\hline MA D & 24 & 1 & 2 & 0 & 0 & 27 \\
\hline & $3.5 \%$ & $7.7 \%$ & $1.8 \%$ & $0.0 \%$ & $0.0 \%$ & \\
\hline VA ED & 24 & 0 & 1 & 1 & 4 & 30 \\
\hline & $3.5 \%$ & $0.0 \%$ & $0.9 \%$ & $2.8 \%$ & $3.8 \%$ & \\
\hline OH ND & 10 & 0 & 0 & 0 & 7 & 17 \\
\hline & $1.5 \%$ & $0.0 \%$ & $0.0 \%$ & $0.0 \%$ & $6.7 \% * *$ & \\
\hline TX SD & 20 & 0 & 1 & 0 & 1 & 22 \\
\hline & $2.9 \%$ & $0.0 \%$ & $0.9 \%$ & $0.0 \%$ & $1.0 \%$ & \\
\hline All Other Dist. & 199 & 9 & 33 & 9 & 13 & 263 \\
\hline & $29.2 \%$ & $69.2 \% * *$ & $29.7 \%$ & $25.0 \%$ & $12.5 \% * *$ & \\
\hline
\end{tabular}

Table A4

Observations by Primary Technology

Operating Company vs. NPE

\begin{tabular}{|c|c|c|c|c|}
\hline $\begin{array}{l}\text { Top Row = Frequency; } \\
\text { Bottom Row } \\
\text { Percentage } \\
*=p<0.05 ; * *=p< \\
0.01 ; * * * p<0.001\end{array}$ & $\begin{array}{l}\text { Operating } \\
\text { Company }\end{array}$ & NPE & Total & $\begin{array}{l}\text { Comp. of proportions } \\
\text { (Fisher's Exact test) p- } \\
\text { value }\end{array}$ \\
\hline \multirow[t]{2}{*}{ Mechanical } & 235 & 36 & 271 & \\
\hline & $34.5 \%$ & $13.6 \%$ & & $<0.001 * * *$ \\
\hline \multirow[t]{2}{*}{ Electrical } & 77 & 27 & 104 & \\
\hline & $11.3 \%$ & $10.2 \%$ & & 0.728 \\
\hline \multirow[t]{2}{*}{ Chemistry } & 149 & 5 & 154 & \\
\hline & $21.9 \%$ & $1.9 \%$ & & $<0.001^{* * *}$ \\
\hline \multirow[t]{2}{*}{ Biotechnology } & 41 & 9 & 50 & \\
\hline & $6.0 \%$ & $3.4 \%$ & & 0.144 \\
\hline \multirow[t]{2}{*}{ Software-All } & 155 & 174 & 329 & \\
\hline & $22.8 \%$ & $65.9 \%$ & & $<0.001^{* * *}$ \\
\hline \multirow[t]{2}{*}{ Software-BusMeth } & 36 & 29 & 65 & \\
\hline & $5.3 \%$ & $11.0 \%$ & & $0.004 * * *$ \\
\hline \multirow[t]{2}{*}{ Software-NonBusMeth } & 119 & 145 & 264 & \\
\hline & $17.5 \%$ & $54.9 \%$ & & $<0.001 * * *$ \\
\hline
\end{tabular}




\begin{tabular}{|l|l|l|l|l|l|} 
Optics & 24 & 13 & 37 & & \\
\hline & $3.5 \%$ & $4.9 \%$ & & & 0.350 \\
\hline Total & 836 & 438 & 1274 & & \\
\hline & & & & & \\
\hline
\end{tabular}

Table A5

Observations by Primary Technology

Operating Company vs. NPE Subtypes

\begin{tabular}{|c|c|c|c|c|c|c|}
\hline $\begin{array}{l}\text { Top Row = } \\
\text { Frequency; } \\
\text { Bottom Row = } \\
\text { Percentage } \\
*=p<0.05 ; * * \\
=p<0.01 ; * * * \\
=p<0.001 \\
\text { (NPE subtypes } \\
\text { compared } \\
\text { w/operating } \\
\text { companies) }\end{array}$ & $\begin{array}{l}\text { Operating } \\
\text { Company }\end{array}$ & University & Individual & $\begin{array}{l}\text { Failed } \\
\text { Startup }\end{array}$ & PAE & Total \\
\hline \multirow[t]{2}{*}{ Mechanical } & 235 & 0 & 29 & 2 & 5 & 271 \\
\hline & $34.5 \%$ & $0.0 \% * *$ & $26.1 \%$ & $5.6 \% * *$ & $4.8 \% * *$ & \\
\hline \multirow[t]{2}{*}{ Electrical } & 77 & 2 & 10 & 8 & 7 & 104 \\
\hline & $11.3 \%$ & $15.4 \%$ & $9.0 \%$ & $22.2 \%$ & $6.7 \%$ & \\
\hline \multirow[t]{2}{*}{ Chemistry } & 149 & 0 & 2 & 3 & 0 & 154 \\
\hline & $21.9 \%$ & $0.0 \% * *$ & $1.8 \%$ & $8.3 \%$ & $0.0 \% * *$ & \\
\hline \multirow[t]{2}{*}{ Biotechnology } & 41 & 2 & 0 & 0 & 7 & 50 \\
\hline & $6.0 \%$ & $15.4 \% * *$ & $0.0 \%$ & $0.0 \%$ & $6.7 \%$ & \\
\hline \multirow[t]{2}{*}{ Software-All } & 155 & 9 & 62 & 23 & 80 & 329 \\
\hline & $22.8 \%$ & $69.2 \% * *$ & $55.9 \% * *$ & $63.9 \% * *$ & $76.9 \% * *$ & \\
\hline \multirow[t]{2}{*}{$\begin{array}{l}\text { Software- } \\
\text { BusMeth }\end{array}$} & 36 & 0 & 8 & 12 & 9 & 65 \\
\hline & $5.3 \%$ & $0.0 \%$ & $7.2 \%$ & $33.3 \% * *$ & $8.7 \%$ & \\
\hline \multirow[t]{2}{*}{$\begin{array}{l}\text { Software- } \\
\text { NonBusMeth }\end{array}$} & 119 & 9 & 54 & 11 & 71 & 264 \\
\hline & $17.5 \%$ & $69.2 \% * *$ & $48.6 \% * *$ & $30.6 \% * *$ & $68.3 \% * *$ & \\
\hline \multirow[t]{2}{*}{ Optics } & 24 & 0 & 8 & 0 & 5 & 37 \\
\hline & $3.5 \%$ & $0.0 \%$ & $7.2 \%$ & $0.0 \%$ & $4.8 \%$ & \\
\hline Total & 836 & 22 & 173 & 59 & 184 & 1274 \\
\hline
\end{tabular}


Table A6

Litigation Outcomes

Operating Companies vs. NPE

\begin{tabular}{|c|c|c|c|c|}
\hline $\begin{array}{l}\text { Top Row = Frequency; } \\
\text { Bottom Row } \\
\text { Percentage } \\
*=\mathrm{p}<0.05 ; * *=\mathrm{p}< \\
0.01 ; * * *=\mathrm{p}<0.001\end{array}$ & $\begin{array}{l}\text { Operating } \\
\text { Company }\end{array}$ & NPE & Total & $\begin{array}{l}\text { Comp. of proportions } \\
\text { (Fisher's Exact test) p- } \\
\text { value }\end{array}$ \\
\hline \multirow[t]{2}{*}{$\begin{array}{l}\text { Invalidity-All } \\
\text { Grounds-Any stage }\end{array}$} & 135 & 53 & 188 & \\
\hline & $40.9 \%$ & $48.2 \%$ & & 0.184 \\
\hline \multirow[t]{2}{*}{$\begin{array}{ll}\text { Invalidity-102 Prior } \\
\text { Art-Any stage }\end{array}$} & 47 & 24 & 71 & \\
\hline & $27.3 \%$ & $42.1 \%$ & & $0.047^{*}$ \\
\hline \multirow[t]{2}{*}{$\begin{array}{l}\text { Invalidity- } \\
\text { Obviousness-Any } \\
\text { Stage } \\
\end{array}$} & 55 & 16 & 71 & \\
\hline & $27.4 \%$ & $42.1 \%$ & & 0.082 \\
\hline \multirow[t]{2}{*}{$\begin{array}{l}\text { Invalidity-Claim } \\
\text { Indefiniteness-Any } \\
\text { Stage }\end{array}$} & 12 & 19 & 31 & \\
\hline & $10.5 \%$ & $31.7 \%$ & & $0.001 * * *$ \\
\hline \multirow[t]{2}{*}{$\begin{array}{l}\text { Invalidity-Written } \\
\text { Description-Any Stage }\end{array}$} & 16 & 3 & 19 & \\
\hline & $19.5 \%$ & $17.6 \%$ & & 1.000 \\
\hline \multirow[t]{2}{*}{$\begin{array}{l}\text { Invalidity-Enablement- } \\
\text { Any Stage }\end{array}$} & 12 & 7 & 19 & \\
\hline & $11.9 \%$ & $70.0 \%$ & & $<0.001 * * *$ \\
\hline \multirow[t]{2}{*}{$\begin{array}{l}\text { Invalidity-Inadequate } \\
\text { Disclosure (Written } \\
\text { Descr \& Enablement } \\
\text { Comb.)-Any Stage }\end{array}$} & 18 & 9 & 27 & \\
\hline & $12.1 \%$ & $45.0 \%$ & & $0.005^{* *}$ \\
\hline \multirow[t]{2}{*}{$\begin{array}{l}\text { Literal Infringement- } \\
\text { Any stage }\end{array}$} & 157 & 31 & 188 & \\
\hline & $41.8 \%$ & $19.3 \%$ & & $<0.001 * * *$ \\
\hline \multirow[t]{2}{*}{$\begin{array}{l}\text { Total Direct } \\
\text { Infringement-Any } \\
\text { Stage }\end{array}$} & 160 & 37 & 197 & \\
\hline & $42.4 \%$ & $22.4 \%$ & & $<0.001 * * *$ \\
\hline \multirow[t]{2}{*}{$\begin{array}{l}\text { Inducement } \\
\text { Infringement-Any } \\
\text { Stage } \\
\end{array}$} & 31 & 6 & 37 & \\
\hline & $44.9 \%$ & $25.0 \%$ & & 0.097 \\
\hline
\end{tabular}




\begin{tabular}{|l|l|l|l|l|l|}
$\begin{array}{l}\text { Contributory } \\
\text { Infringement-Any } \\
\text { Stage }\end{array}$ & 21 & 8 & 29 & & \\
\hline & $46.7 \%$ & $33.3 \%$ & & & 0.317 \\
\hline & & & & & \\
Total & 1625 & 558 & 2183 & & \\
\hline & & & & & \\
\hline
\end{tabular}

Table A7

Litigation Outcomes

Operating Companies vs. NPE Subtypes

\begin{tabular}{|c|c|c|c|c|c|c|}
\hline 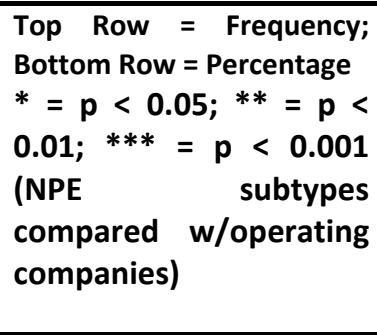 & $\begin{array}{l}\text { Operating } \\
\text { Company }\end{array}$ & University & Individual & $\begin{array}{l}\text { Failed } \\
\text { Startup }\end{array}$ & PAE & Total \\
\hline $\begin{array}{l}\text { Invalidity-All Grounds- } \\
\text { Any stage }\end{array}$ & 135 & 0 & 33 & 6 & 14 & 188 \\
\hline & $40.9 \%$ & $0.0 \%$ & $56.8 \% *$ & $40.0 \%$ & $42.4 \%$ & \\
\hline $\begin{array}{l}\text { Invalidity-102 Prior Art-Any } \\
\text { stage }\end{array}$ & 47 & 0 & 17 & 3 & 4 & 71 \\
\hline & $27.3 \%$ & $0.0 \%$ & $54.8 \% * *$ & $23.1 \%$ & $40.0 \%$ & \\
\hline $\begin{array}{l}\text { Invalidity-Obviousness-Any } \\
\text { Stage }\end{array}$ & 55 & 0 & 12 & 1 & 3 & 71 \\
\hline & $27.4 \%$ & $0.0 \%$ & $60.0 \% * *$ & $14.3 \%$ & $37.5 \%$ & \\
\hline $\begin{array}{l}\text { Invalidity-Claim } \\
\text { Indefiniteness-Any Stage }\end{array}$ & 12 & 0 & 8 & 1 & 10 & 31 \\
\hline & $10.5 \%$ & $0.0 \%$ & $27.6 \% *$ & $33.3 \%$ & $38.5 \% * *$ & \\
\hline $\begin{array}{l}\text { Invalidity-Written } \\
\text { Description-Any Stage }\end{array}$ & 16 & 0 & 2 & 1 & 0 & 19 \\
\hline & $19.5 \%$ & $0.0 \%$ & $25.0 \%$ & $33.3 \%$ & $0.0 \%$ & \\
\hline $\begin{array}{l}\text { Invalidity-Enablement-Any } \\
\text { Stage }\end{array}$ & 12 & 0 & 6 & 1 & 0 & 38 \\
\hline & $11.9 \%$ & $0.0 \%$ & $75.0 \% * *$ & $100.0 \%$ & $0.0 \%$ & \\
\hline
\end{tabular}




\begin{tabular}{|c|c|c|c|c|c|c|}
\hline $\begin{array}{l}\text { Invalidity-Inadequate } \\
\text { Disclosure (Written Descr } \\
\text { \& Enablement Comb.)-Any } \\
\text { Stage }\end{array}$ & 18 & 0 & 7 & 2 & 0 & 54 \\
\hline & $12.1 \%$ & $0.0 \%$ & $70.0 \% * *$ & $66.7 \%$ & $0.0 \%$ & \\
\hline $\begin{array}{l}\text { Literal Infringement-Any } \\
\text { stage }\end{array}$ & 157 & 3 & 10 & 6 & 12 & 188 \\
\hline & $41.8 \%$ & $33.3 \%$ & $19.6 \% * *$ & $25.0 \%$ & $15.6 \% * *$ & \\
\hline $\begin{array}{l}\text { Total Direct Infringement- } \\
\text { Any Stage }\end{array}$ & 160 & 3 & 16 & 6 & 12 & 197 \\
\hline & $42.4 \%$ & $30.0 \%$ & $29.6 \%$ & $25.0 \%$ & $15.6 \%$ & \\
\hline $\begin{array}{l}\text { Inducement Infringement- } \\
\text { Any Stage }\end{array}$ & 31 & 2 & 1 & 0 & 3 & 37 \\
\hline & $44.9 \%$ & $100.0 \%$ & $20.0 \%$ & $0.0 \%$ & $21.4 \%$ & \\
\hline $\begin{array}{l}\text { Contributory Infringement- } \\
\text { Any Stage }\end{array}$ & 21 & 2 & 3 & 0 & 3 & 29 \\
\hline & $46.7 \%$ & $100.0 \%$ & $100.0 \%$ & $0.0 \%$ & $21.4 \%$ & \\
\hline Total & 1625 & 24 & 277 & 76 & 227 & 2229 \\
\hline
\end{tabular}

Table 10

Logistic Regression on Outcomes-Operating Co. v. NPE Controlling for Primary Technology Areas, Three Busiest Districts, And Patent \& Litigation Characteristics

\begin{tabular}{|c|c|c|c|c|c|}
\hline $\begin{array}{l}\text { Top row }=\text { Logit } \\
\text { Coefficient; } *=p< \\
0.05 ; * *=p<0.01 ; * * * \\
=p<0.001 \text { Bottom } \\
\text { row }=\text { standard error }\end{array}$ & $\begin{array}{l}\text { Patent Owner } \\
\text { Definitive Win }\end{array}$ & $\begin{array}{l}\text { SJ Invalidity-All } \\
\text { Grounds-Any } \\
\text { Stage }\end{array}$ & $\begin{array}{l}\text { SJ Non- } \\
\text { infringement }\end{array}$ & $\begin{array}{l}\text { SJ Non-infringement } \\
+\quad \text { Stip. Jgmt of } \\
\text { Noninfringement }\end{array}$ & $\begin{array}{l}\text { Patent } \\
\text { Owner Trial } \\
\text { Winner }\end{array}$ \\
\hline $\begin{array}{l}\text { Broad NPE (Base } \\
\text { category is Operating } \\
\text { Company) }\end{array}$ & $-0.918^{*}$ & 0.631 & $0.828^{*}$ & $0.890 *$ & -0.380 \\
\hline & $(0.450)$ & $(0.488)$ & $(0.383)$ & $(0.442)$ & $(0.664)$ \\
\hline $\begin{array}{l}\text { Declaratory Judgment } \\
\text { control }\end{array}$ & $x$ & $x$ & $x$ & $x$ & $x$ \\
\hline
\end{tabular}




\begin{tabular}{|c|c|c|c|c|c|}
\hline $\begin{array}{l}\text { Patent demographic } \\
\text { controls }{ }^{159}\end{array}$ & $x$ & $x$ & $x$ & $\mathrm{x}$ & $x$ \\
\hline $\begin{array}{l}\text { Litigation } \\
\text { demographic } \\
\text { controls }^{160}\end{array}$ & $x$ & $x$ & $x$ & $x$ & $x$ \\
\hline ANDA case control & $\mathrm{x}$ & $\mathrm{x}$ & $x$ & $\mathrm{x}$ & $\mathrm{x}$ \\
\hline \multirow[t]{2}{*}{ TX-ED } & $1.370 * *$ & $-1.106 *$ & $-0.815^{*}$ & $-0.752^{*}$ & 0.392 \\
\hline & -0.368 & -0.475 & -0.32 & -0.375 & -0.522 \\
\hline \multirow[t]{2}{*}{ D-DE } & -0.0686 & -0.421 & 0.325 & 0.314 & $-0.806^{*}$ \\
\hline & -0.299 & -0.568 & -0.32 & -0.306 & -0.355 \\
\hline \multirow[t]{2}{*}{ CA-ND } & 0.0646 & 0.655 & 0.411 & 0.406 & -0.681 \\
\hline & -0.366 & -0.393 & -0.42 & -0.413 & -0.73 \\
\hline \multicolumn{6}{|c|}{ Comparison dummy for 3 districts is all other districts } \\
\hline \multicolumn{6}{|l|}{ Technology controls } \\
\hline $\begin{array}{l}\text { Interaction } \\
\text { (Broad_NPE } \\
\text { Software) }\end{array}$ & 0.114 & 0.133 & -0.072 & -0.103 & 0.147 \\
\hline & $\begin{array}{l}-- \\
0.117\end{array}$ & -.236 & -.105 & -.13 & -0.671 \\
\hline
\end{tabular}

159 Patent demographic controls include adjusted number of forward citations, foreign origin of invention, total prior art reference, and age of patent at litigation filing.

160 Litigation demographic controls include age of patent at litigation filing, number of accused infringers, number of asserted patents, and number of lawsuits on patent through Dec. 31, 2009.

${ }^{161}$ An interaction term captures the effect of one independent variable on the effect of the other independent variable on the dependent variable. Here, the interaction term measures whether the effect that a patent being in the primary software technology has on a particular outcome is itself affected by the additional fact of the patent owner being an NPE (using the broad NPE definition). All regression coefficients measure magnitude and direction of effect.

We report our transformed interaction coefficient. An untransformed interaction coefficient in logistic regression reveals only part of the picture. Some researchers have erroneously interpreted the coefficient of an interaction in logistic regression by omitting the second-order term in the interaction effect. That is, they have assumed a linear relationship between the independent variables the interaction of which is being measured. See Chunrong Ai \& Edward C. Norton, Interaction Terms in Logit and Probit Models, 80 ECONOMICS LETTERS 123 (2003). The relationship is not linear because the interaction term is also affected by the values of all other independent variables in the model. The interaction effect between the two independent variables (Software and Broad_NPE) is captured by

$\frac{\partial^{2} G(\cdot)}{\partial \mathrm{x}_{1} \partial x_{2}}=\beta_{12} G^{\prime}(\cdot)+\left(\beta_{2}+\beta_{12} x_{2}\right)\left(\beta_{2}+\beta_{12} x_{2}\right)\left(\beta_{2}+\beta_{12} x_{1}\right) G^{\prime \prime}(\cdot)$. Id. We transformed our coefficient and report the true interaction coefficient. 


\begin{tabular}{|l|l|l|l|l|l|}
$\begin{array}{l}\text { F-test for joint } \\
\text { technology effects }\end{array}$ & $29.48^{* *}$ & 0.57 & 3.06 & 2.31 & 5.83 \\
\hline & & & & & \\
\hline Observations & 632 & 407 & 471 & 506 & 288 \\
\hline
\end{tabular}

\begin{tabular}{|c|c|c|c|c|c|c|}
\hline $\begin{array}{l}\text { Top row }= \\
\text { Coefficient; }{ }^{*}= \\
*=\mathrm{p}<0.05 ; \\
* *=\mathrm{p}<0.01 ; \\
* * *=\mathrm{p}< \\
0.001 \\
\text { Bottom row }= \\
\text { standard error }\end{array}$ & $\begin{array}{l}\text { Invalidity-All } \\
\text { Grounds-Any } \\
\text { Stage }\end{array}$ & $\begin{array}{l}\text { Invalidity- } \\
\text { Sec. } \quad 102 \\
\text { Prior Art- } \\
\text { Any Stage }\end{array}$ & $\begin{array}{l}\text { Invalidity- } \\
\text { Obviousness- } \\
\text { Any Stage }\end{array}$ & $\begin{array}{l}\text { Invalidity- } \\
\text { Indefiniteness- } \\
\text { Any Stage }\end{array}$ & $\begin{array}{l}\text { Literal } \\
\text { Infringement- } \\
\text { Any Stage }\end{array}$ & $\begin{array}{l}\text { Total Direct } \\
\text { Infringement- } \\
\text { Any Stage }\end{array}$ \\
\hline $\begin{array}{l}\text { Operating Co. } \\
\text { (compared with } \\
\text { Broad_NPE) }\end{array}$ & $-1.204 * *$ & $-1.803^{* *}$ & -0.756 & -1.490 & $0.820^{* *}$ & 0.364 \\
\hline & -0.554 & -0.856 & -0.598 & -10.236 & -0.364 & -0.367 \\
\hline $\begin{array}{l}\text { Declaratory } \\
\text { Judgment } \\
\text { control }\end{array}$ & $\mathrm{x}$ & $\mathrm{x}$ & $x$ & $\mathrm{x}$ & $\mathrm{x}$ & $\mathrm{x}$ \\
\hline $\begin{array}{l}\begin{array}{l}\text { Patent } \\
\text { demographic } \\
\text { controls }{ }^{162}\end{array} \\
\end{array}$ & $\mathrm{x}$ & $\mathrm{x}$ & $\mathrm{x}$ & $x$ & $\mathrm{x}$ & $x$ \\
\hline $\begin{array}{l}\text { Litigation } \\
\text { demographic } \\
\text { controls }{ }^{163}\end{array}$ & $\mathrm{x}$ & $\mathrm{x}$ & $x$ & $\mathrm{x}$ & $x$ & $\mathrm{x}$ \\
\hline $\begin{array}{ll}\text { ANDA } & \text { case } \\
\text { control }\end{array}$ & $x$ & $\mathrm{x}$ & $x$ & $x$ & $\mathrm{x}$ & $x$ \\
\hline TX-ED & $-1.415^{* * *}$ & $-1.488^{* *}$ & -0.523 & -0.982 & $0.962^{* * *}$ & $0.918 * * *$ \\
\hline & -0.388 & -1.267 & -1.123 & -0.975 & -0.356 & -0.374 \\
\hline DE-D & 0.249 & -0.216 & -0.097 & 1.939 & -0.219 & -0.0680 \\
\hline & -0.345 & -0.747 & -0.52 & -1.676 & -0.313 & -0.295 \\
\hline CA-ND & $0.895^{* *}$ & 1.223 & 0.981 & 0.835 & $-1.060 *$ & $-1.120 * *$ \\
\hline & -0.436 & -0.844 & -0.703 & -0.866 & -0.474 & -0.583 \\
\hline Comparison dum & ny for 3 distric & all other distric & & & & \\
\hline $\begin{array}{l}\text { Technology } \\
\text { controls }\end{array}$ & $x$ & $\mathrm{x}$ & $x$ & $\mathrm{x}$ & $\mathrm{x}$ & $\mathrm{x}$ \\
\hline $\begin{array}{l}\text { Interaction } \\
\text { (Broad_NPE \& } \\
\text { Software) }\end{array}$ & -0.161 & -0.227 & -0.099 & 0.06 & 0.063 & 0.002 \\
\hline & -0.296 & -0.837 & -1.296 & -0.692 & -0.17 & -0.113 \\
\hline
\end{tabular}

162 Patent demographic controls include adjusted number of forward citations, foreign origin of invention, total prior art reference, and age of patent at litigation filing.

163 Litigation demographic controls include age of patent at litigation filing, number of accused infringers, number of asserted patents, and number of lawsuits on patent through Dec. 31, 2009. 


\begin{tabular}{|l|l|l|l|l|l|l|}
$\begin{array}{l}\text { F-test for joint } \\
\text { technology } \\
\text { effects }\end{array}$ & 6.82 & 3.54 & $555.57^{* * *}$ & 1.54 & $13.09^{* *}$ & $17.54^{* * *}$ \\
\hline & $(0.234)$ & $(0.617)$ & $(0.000)$ & $(0.673)$ & $(0.023)$ & $(0.0036)$ \\
\hline & & & & & & \\
\hline & & & & & & \\
\hline & & 229 & 239 & 127 & 537 & 542 \\
\hline
\end{tabular}

Table 11

Logistic Regression on Outcomes

NPE Subtypes with Operating Companies as the Comparison Dummy

Controlling for Primary Technology Areas, Three Busiest Districts, And Patent \& Litigation Characteristics

\begin{tabular}{|c|c|c|c|c|c|}
\hline $\begin{array}{l}\text { Top row }=\text { Coefficient; } \\
=\mathrm{p}<0.05 ; * *=\mathrm{p}< \\
0.01 ; * * *=\mathrm{p}<0.001 ; \\
\text { Bottom row = standard } \\
\text { error }\end{array}$ & $\begin{array}{l}\text { Patent Owner } \\
\text { Definitive Win }\end{array}$ & $\begin{array}{l}\text { SJ Invalidity-All } \\
\text { Grounds-Any } \\
\text { Stage }\end{array}$ & $\begin{array}{l}\text { SJ Non- } \\
\text { infringement }\end{array}$ & $\begin{array}{l}\text { SJ Non-infringement } \\
+ \text { Stip. Jgmt of } \\
\text { Noninfringement }\end{array}$ & $\begin{array}{l}\text { Patent } \\
\text { Owner Trial } \\
\text { Winner }\end{array}$ \\
\hline \multirow[t]{2}{*}{ Individual } & -0.559 & -0.060 & 0.921 & 1.185 & -0.752 \\
\hline & $(3.308)$ & (3.496) & $(0.580)$ & $(0.863)$ & $(0.642)$ \\
\hline \multirow[t]{2}{*}{ Failed Startup } & -0.980 & 1.113 & 0.791 & 0.665 & $-0.529+$ \\
\hline & $(6.697)$ & $(4.277)$ & $(4.541)$ & $(0.716)$ & $(0.320)$ \\
\hline \multirow[t]{2}{*}{ University } & $-9.965 * * *$ & 0.000 & -0.744 & -0.791 & 0.000 \\
\hline & $(1.281)$ & $(0.000)$ & (7.417) & $(6.785)$ & $(0.000)$ \\
\hline \multirow[t]{2}{*}{ PAE } & -2.149 & 2.221 & 1.077 & 0.848 & $16.826^{*}$ \\
\hline & $(4.320)$ & $(4.066)$ & $(2.724)$ & $(1.173)$ & (7.835) \\
\hline \multicolumn{6}{|c|}{ Comparison dummy is operating company } \\
\hline $\begin{array}{l}\text { Declaratory Judgment } \\
\text { control }\end{array}$ & $\mathrm{x}$ & $x$ & $\mathrm{x}$ & $x$ & $x$ \\
\hline $\begin{array}{l}\text { Patent demographic } \\
\text { controls }\end{array}$ & $\mathrm{x}$ & $\mathrm{x}$ & $\mathrm{x}$ & $\mathrm{x}$ & $x$ \\
\hline $\begin{array}{l}\text { Litigation demographic } \\
\text { controls }\end{array}$ & $\mathrm{x}$ & $\mathrm{x}$ & $x$ & $\mathrm{x}$ & $x$ \\
\hline ANDA case control & $\mathrm{x}$ & $\mathrm{x}$ & $\mathrm{x}$ & $\mathrm{x}$ & $x$ \\
\hline \multirow[t]{2}{*}{ TX-ED } & $1.489 * * *$ & $-1.289 *$ & $-0.796+$ & $-0.754+$ & 0.420 \\
\hline & $(0.367)$ & $(0.575)$ & $(0.424)$ & $(0.428)$ & $(0.738)$ \\
\hline \multirow[t]{2}{*}{ D-DE } & -0.019 & -0.602 & 0.370 & 0.369 & $-0.887^{*}$ \\
\hline & $(0.267)$ & $(0.625)$ & $(0.409)$ & $(0.425)$ & $(0.372)$ \\
\hline \multirow[t]{2}{*}{ CA-ND } & 0.123 & 0.550 & 0.390 & 0.387 & -0.751 \\
\hline & $(0.394)$ & $(0.474)$ & $(0.347)$ & $(0.379)$ & $(0.606)$ \\
\hline
\end{tabular}


[DO NON-PRACTICING ENTITIES WIN?] DRAFT

\begin{tabular}{|l|l|l|l|l|l|}
\hline \multicolumn{2}{|l|}{ Comparison dummy is all other districts } & & & \\
\hline Technology control & $\mathrm{x}$ & $\mathrm{x}$ & $\mathrm{x}$ & $\mathrm{x}$ & $\mathrm{x}$ \\
\hline $\begin{array}{l}\text { Interaction (Individual } \\
\text { \& Software) }\end{array}$ & 0.005 & 0.296 & 0.004 & -0.067 & 0.067 \\
\hline & $(0.409)$ & $(0.882)$ & $1.469)$ & $(1.222)$ & $0.897)$ \\
\hline $\begin{array}{l}\text { Interaction (Failed } \\
\text { Startup \& Software) }\end{array}$ & 0.120 & 0.122 & -0.357 & -0.339 & 0.248 \\
\hline & $(0.318)$ & $(1.000)$ & $(2.302)$ & $(2.025)$ & $(0.926)$ \\
\hline $\begin{array}{l}\text { Interaction (University } \\
\text { \& Software) }\end{array}$ & 0.632 & 0.000 & 0.108 & 0.108 & 0.000 \\
\hline & $(1.358)$ & $(0.000)$ & $(2.172)$ & $(1.766)$ & $(0.000)$ \\
\hline $\begin{array}{l}\text { Interaction (PAE \& } \\
\text { Software) }\end{array}$ & 0.195 & -0.158 & -0.123 & -0.095 & -0.283 \\
\hline & $0.554)$ & $(0.704)$ & $(1.808)$ & $(1.432)$ & $(2.684)$ \\
\hline Observations & 632 & 400 & 471 & 506 & 285 \\
\hline
\end{tabular}

\begin{tabular}{|c|c|c|c|c|c|c|}
\hline $\begin{array}{l}\text { Top row }=\text { Coefficient; }{ }^{*}= \\
p<0.05 ; * *=p<0.01 ;{ }^{* * *} \\
=p<0.001 ; \text { Bottom row }= \\
\text { standard error }\end{array}$ & $\begin{array}{l}\text { Invalidity-All } \\
\text { Grounds- } \\
\text { Any Stage } \\
\end{array}$ & $\begin{array}{l}\text { Invalidity- } \\
\text { Sec. } \quad 102 \\
\text { Prior Art- } \\
\text { Any Stage } \\
\end{array}$ & $\begin{array}{l}\text { Invalidity- } \\
\text { Obviousness- } \\
\text { Any Stage }\end{array}$ & $\begin{array}{l}\text { Invalidity- } \\
\text { Indefiniteness- } \\
\text { Any Stage }\end{array}$ & $\begin{array}{l}\text { Literal } \\
\text { Infringement- } \\
\text { Any Stage }\end{array}$ & $\begin{array}{l}\text { Total Direct } \\
\text { Infringement- } \\
\text { Any Stage } \\
\end{array}$ \\
\hline \multirow[t]{2}{*}{ Individual } & 0.775 & 1.428 & 0.957 & 0.290 & $-0.993 *$ & -0.251 \\
\hline & $(0.560)$ & (5.378) & (4.891) & (4.532) & (0.411) & $(0.597)$ \\
\hline \multirow[t]{2}{*}{ Failed Startup } & $14.755^{* * *}$ & $16.262^{* * *}$ & -0.653 & 2.104 & -0.850 & -0.867 \\
\hline & $(1.503)$ & $(1.511)$ & $(1.355)$ & $(1.959)$ & (6.349) & $(6.709)$ \\
\hline \multirow[t]{2}{*}{ University } & 0.000 & 0.000 & 0.000 & 0.000 & $-13.326 * * *$ & $-13.130 * * *$ \\
\hline & $(0.000)$ & $(0.000)$ & $(0.000)$ & $(0.000)$ & $(1.301)$ & $(1.187)$ \\
\hline \multirow[t]{2}{*}{ PAE } & 2.456 & 2.595 & -0.123 & 3.284 & -0.369 & -0.330 \\
\hline & $(6.157)$ & $(5.286)$ & $(16.704)$ & $(14.055)$ & $(0.779)$ & $(0.775)$ \\
\hline \multicolumn{7}{|c|}{ Comparison dummy is operating company } \\
\hline $\begin{array}{ll}\begin{array}{l}\text { Declaratory Judgment } \\
\text { control }\end{array} \\
\end{array}$ & $\mathrm{x}$ & $\mathrm{x}$ & $\mathrm{x}$ & $\mathrm{x}$ & $\mathrm{x}$ & $\mathrm{x}$ \\
\hline $\begin{array}{ll}\text { Patent } & \text { demographic } \\
\text { controls } & \\
\end{array}$ & $\mathrm{x}$ & $\mathrm{x}$ & $\mathrm{x}$ & $\mathrm{x}$ & $\mathrm{x}$ & $\mathrm{x}$ \\
\hline $\begin{array}{l}\text { Litigation demographic } \\
\text { controls }\end{array}$ & $x$ & $x$ & $x$ & $x$ & $x$ & $x$ \\
\hline ANDA case control & $\mathrm{x}$ & $x$ & $x$ & $x$ & $x$ & $x$ \\
\hline \multirow[t]{2}{*}{ TX-ED } & $-1.600 * * *$ & -1.474 & -0.588 & -1.441 & $1.056^{*}$ & $0.987^{*}$ \\
\hline & $(0.474)$ & $(1.412)$ & $(0.789)$ & $(1.732)$ & $(0.456)$ & $(0.456)$ \\
\hline \multirow[t]{2}{*}{ D-DE } & 0.177 & -0.288 & -0.045 & 2.167 & -0.207 & -0.036 \\
\hline & $(0.334)$ & $(0.512)$ & $(0.260)$ & $(1.850)$ & $(0.373)$ & $(0.300)$ \\
\hline \multirow[t]{2}{*}{ CA-ND } & $0.939 * *$ & 1.245 & 1.058 & 1.024 & $-1.017^{*}$ & $-1.078^{*}$ \\
\hline & $(0.314)$ & $(0.752)$ & $(0.549)$ & $(1.062)$ & $(0.472)$ & $(0.504)$ \\
\hline \multicolumn{7}{|c|}{ Comparison dummy for 3 districts is all other districts } \\
\hline Technology controls & $x$ & $x$ & $x$ & $x$ & $x$ & $x$ \\
\hline
\end{tabular}


[DO NON-PRACTICING ENTITIES WIN?] DRAFT

\begin{tabular}{|l|l|l|l|l|l|l|}
$\begin{array}{l}\text { Interaction (Individual \& } \\
\text { Software) }\end{array}$ & 0.045 & -0.014 & -0.070 & 0.374 & 0.005 & -0.056 \\
\hline & $(0.346)$ & $(0.544)$ & $(1.516)$ & $(1.842)$ & $(0.393)$ & $(0.298)$ \\
\hline $\begin{array}{l}\text { Interaction (Failed Startup } \\
\text { \& Software) }\end{array}$ & -0.545 & -0.676 & 0.049 & 0.066 & 0.063 & 0.062 \\
\hline & $(0.619)$ & $(1.257)$ & $(1.152)$ & $(1.240)$ & $(0.285)$ & $(0.308)$ \\
\hline $\begin{array}{l}\text { Interaction (University \& } \\
\text { Software) }\end{array}$ & 0.000 & 0.000 & 0.000 & 0.000 & 0.588 & 0.562 \\
\hline & $(0.000)$ & $(0.000)$ & $(0.000)$ & $(0.000)$ & $(0.885)$ & $(0.856)$ \\
\hline $\begin{array}{l}\text { Interaction (PAE \& } \\
\text { Software) }\end{array}$ & -0.498 & -0.387 & 0.034 & -0.262 & -0.041 & -0.049 \\
\hline & $(0.651)$ & $(0.850)$ & $(0.385)$ & $(0.800)$ & $(0.309)$ & $(0.317)$ \\
\hline Observations & 436 & 226 & 236 & 125 & 537 & 542 \\
\hline
\end{tabular}

